\title{
CAMINHOS DE SOPRO: DISCURSO XAMÂNICO E PERCURSOS FLORESTAIS DOS HUPD'ÄH
}

Danilo Paiva Ramos

Patience Epps*

\section{Introdução}

Os Hupd'äh foram descritos pela literatura etnográfica até os anos 1990 como um povo "caçador especialista" dotado de um alto grau de mobilidade (Reid 1979; Silverwood-Cope 1990). Caracterizados como nômades ou seminômades, os Hupd'äh figuravam como o contraponto necessário dos povos Tukano, ribeirinhos, de economia agrícola e pesqueira, cuja estrutura social hierarquizada (sibs), os rituais elaborados e o xamanismo foram objeto de interesse de inúmeros pesquisadores (Reichel-Dolmatoff 1986; Buchillet 1983, 1992; S. Hugh-Jones 1979; C. Hugh-Jones 1979; Jackson 1983, dentre outros). O fato de famílias hup realizarem trocas constantes com famílias tukano, de trabalharem em suas roças durante certos períodos e de serem considerados, pelos Tukano, como "servos", inferiores hierarquicamente, autorizou a elaboração de modelos científicos que viram nas relações interétnicas desses povos aspectos de uma sociabilidade simbiótica, assimétrica ou patronal (Ramos et al. 1981). Mesmo os etnógrafos que estudaram intensamente os Hupd'äh, influenciados por tal visão acadêmica, descreveram-nos como um povo de "fraco xamanismo" e com "rituais pouco elaborados" (Reid 1978:4-5; Silverwood-Cope 1990).

Como apontado por Beier, Michael e Sherzer (2002), os estudos sobre formas e práticas discursivas ameríndias vêm abordando o discurso xamânico como uma linguagem especial que difere da linguagem cotidiana através de suas fonologia, morfologia, sintaxe, semântica, forma discursiva, modalidade, do seu léxico, do contexto de enunciação e das práticas vocais, como cantos, murmúrios, sopros, dentre outros. É uma forma discursiva correntemente associada às curas, a práticas divinatórias e à magia (Bidou \& Perrin 1988). Diversos autores têm enfatizado a recorrência de elementos discursivos que remetem a itinerários, caminhos, deslocamentos que corroboram para a percepção dos xamãs como "viajantes por excelência" 
que nomeiam o que veem em "outros mundos" (Cesarino 2013a, 2013b; Carneiro da Cunha 1998; Perrin 2001; Langdon 2013; Chaumeil 1983; Severi 2002; Gallois 1996; Hill 1989, 1993, 2011; Buchillet 1983, 1992; Reichel-Dolmatoff 1978, 1986). ${ }^{1}$

Ingold (2000) enfatiza os processos mútuos de coabitação entre humanos e organismos em paisagens entendidas como campos mútuos de percepção e ação. Em sua ecologia sensível, o "mundo da cultura", constituído pelas abordagens semióticas, perde sua força, e os modos de significação e conhecimento passam a ser vistos como ontogenéticos, processos criativos em que os seres em interação e movimento adquirem e incorporam habilidades uns com os outros. Viveiros de Castro $(1998,2002)$ mostra como o xamanismo ameríndio, ao perceber animais, plantas e objetos como humanos (seres dotados de intenção, agência, cognição e sociabilidade) situados a partir de seus mundos e pontos de vista, configura um modo perspectivista de pensamento. Denotando a condição social de pessoa por meio de marcadores enunciativos, os povos amazônicos compõem uma deixis cosmológica em que o ambiente e as relações entre humanos e não humanos realiza-se a partir de processos de subjetivação relacionais. ${ }^{2}$ Assim, é possível perceber como a relação entre discurso, espaço e conhecimento vem envolvendo a reflexão sobre a relação entre sujeito e mundo, os modos de perceber e nomear o espaço, os animais e os espíritos, bem como uma nova atitude quanto à memória e à mito-história.

Segundo Chernela e Leed (1996:131), a "viagem" seria a metáfora fundamental do ritual xamânico no Alto Rio Negro. Os autores refletem a tônica dos estudos sobre o xamanismo de povos do Noroeste amazônico, que vem sinalizando a importância da análise de rotas, caminhos e itinerários que levam a lugares sagrados ou "paisagens míticas" (Chernela \& Leed 1996), para entender as práticas de manejo etnoambiental, as toponímias, as antigas redes de comércio e intercâmbio interétnicos, o profetismo indígena arawak e tukano, as estratégias e as revoltas indígenas contra o Estado colonial (Vidal 1999, 2000; Vidal \& Zucchi 2000; Hill 2011; Wright 2013; Hugh-Jones 2012; Cayón 2008). Para tanto, a atenção analítica para as narrativas míticas, a história oral, os cantos rituais e os encantamentos xamânicos vem mostrando como o xamanismo e as cosmologias arawak e tukano fundamentam a intensa mobilidade e as redes de troca interétnicas que deram forma ao sistema regional rio-negrino (Neves 2001, 2011; Cayón 2008; Cayón \& Chacon 2014).

O presente trabalho busca evidenciar como o discurso xamânico e a mobilidade territorial podem ser vistos como modos de ação que, ao lançar xamãs e viajantes em percursos sociocósmicos, delineiam formas sensíveis 
de estabelecimento de sentido ao mundo vivido dos Hupd'äh. ${ }^{3}$ Para tanto, toma-se em paralelo a sequência de ações narradas pelo benzedor Ponciano Ramos na exegese do "benzimento dos caminhos" e eventos ocorridos ao longo de viagens a morros e lugares sagrados realizadas em companhia de anciões e jovens. Procura-se observar o modo como os diálogos (exegese) e os encontros (caminhos) transespecíficos com animais e espíritos situam processos de educação da atenção para uma deixis cosmológica - pronomes e dêiticos referidos à condição de pessoa de humanos e não humanos posicionados (Viveiros de Castro 1998:476) - que vai revelando a posição e os pontos de vista de sujeitos habitantes de "casas", /mòy/, e "terras/mundos", /s'áh/, atravessados pelos passos dos viajantes e pelo sopro vital do benzedor (Ingold 2000, cap. 13:237; Viveiros de Castro 2002).

Nesse sentido, a formulação de Viveiros de Castro (2004) sobre a equivocação controlada como "um tipo de disjunção comunicativa onde os interlocutores não falam da mesma coisa e sabem disso" (Viveiros de Castro 2004:9) torna-se especialmente interessante para analisar os diálogos e as interações transespecíficas. Para entender modos de comunicação entre diferentes posições perspectivas, mostra-se fundamental uma abordagem da tradução xamânica que não busque sinônimos na tentativa de traçar uma representação correferencial (2004:5-7). Comparar como diferentes tipos de corpos experienciam o mundo enquanto uma multiplicidade afectual leva a perceber os modos como a comunicação se dá a partir de suas posições perspectivas (Viveiros de Castro 2004:7).

Desta forma, os elementos linguísticos que possibilitam caracterizar situações de locução, os dêiticos, adquirem valor cosmológico crucial. Como mostra Viveiros de Castro (1996), para o xamanismo ameríndio, as palavras para "'ser humano' denotam não a humanidade como espécie natural, mas a condição social de pessoa [...] menos como substantivos que como pronomes" (1996:125), expressando um "nós" de autorreferência para a pessoa. Se os animais e os espíritos são "gente", são igualmente pessoas, e é preciso estar atento ao ponto de vista de quem fala (jaguar, tartaruga, planta) para entender suas agência e intencionalidade consciente que definem sua posição de sujeito. A alma, o corpo são dêiticos que apontam para a posição e o ponto de vista dos sujeitos a situarem-se pelo diálogo interespecífico (1996:126).

De modo complementar, o princípio de educação da atenção trabalhado por Ingold (2000, cap. 8:146) ajuda a descrever os caminhos e a exegese como percursos de observação através dos quais os jovens hupd'äh iniciantes praticam maneiras de situar-se em múltiplos campos ontológicos, seguem os atos de mostrar dos mentores e aprendem à medida que "fazem 
os caminhos florestais" e "fazem os itinerários xamânicos". Tomando o conceito de mundo vivido de Gow (2001), a descrição fina dessas formas sensíveis, discursivas e ambulatórias permite sinalizar a importância do modo como o mundo vivido dos Hupd'äh, na tessitura de caminhos e lugares sagrados, articula-se paralela e contrapontisticamente ao sociocosmos rio-negrino (Gow 2001).

\section{Mobilidade e discurso no Alto Rio Negro}

Nos estudos sobre os povos do Alto Rio Negro, vem sendo cada vez mais importante a observação da relação entre discurso xamânico e mobilidade. Para Cayón e Chacon (2014), o enfoque sobre caminhos de cura e toponímias, por exemplo, que começou recentemente a ser explorado de modo interdisciplinar por trabalhos etnológicos, arqueológicos, linguísticos e etnobotânicos, é visto como central para refinar o conhecimento científico sobre o sistema regional do Alto Rio Negro. No mesmo sentido, os movimentos indígenas regionais vêm tomando o mapeamento de lugares sagrados e o registro de narrativas a eles associadas como ações fundamentais para o estabelecimento da autogestão territorial e ambiental, bem como para o reconhecimento pela Unesco do sistema de conhecimento dos xamãs jaguares do Jurupari, e pelo Iphan das cachoeiras de Iauareté como patrimônio imaterial brasileiro (Andrello et al. 2012).

Chama a atenção o fato de que o foco de estudos e ações políticas incida principalmente sobre rotas que margeiam os grandes rios e igarapés regionais, deixando de lado os caminhos florestais e as vastas áreas interfluviais (ver Vidal 2000; Hill 2011; Wright 2013). Muitos lugares sagrados ou lugares de memória estão marcados com petróglifos, cachoeiras e morros (Hugh-Jones 2012). Segundo Wright (2013), esses lugares de criação de pessoas e ordenamento social seriam paisagens míticas (mythscapes), historicamente importantes para a sociopolítica, a migração e o comércio regionais. Narrativas míticas, cantos, músicas e encantamentos xamânicos surgem como veículos de conhecimento, estabelecendo sequências lineares de lugares ao longo de rios e morros, mas também, de modo perpendicular, nomeiam-se espíritos, espécies animais e vegetais e objetos rituais próprios de cada um desses lugares (Hugh-Jones 2012).

Como mostra Århem (1998), a sequência de nomes associados a lugares remete a conhecimentos e poderes imanentes às malocas, pedras, espécies e aos objetos rituais. No mesmo sentido, Cayón (2008) ressalta que o discurso xamânico codifica conhecimentos sobre o mundo e seus seres e que o complexo ritual do Jurupari dá vida a todos os seres e reconstrói o cosmos a partir da referência aos lugares da viagem dos demiurgos 
ancestrais, realizando a ação xamânica de "encantamento do mundo" fundamental ao "manejo do mundo" (Cayón 2008; Cayón \& Chacon 2014).

Como propõem Cayón e Chacon (2014), seria possível tomar o sistema regional do Alto Rio Negro como um sistema multiétnico de geografias xamânicas a vincular pessoas e grupos ao espaço onde vivem, tecendo conexões históricas com ancestrais e com os demais seres que povoam o mundo. Desviantes em relação a esse padrão por terem mantido o modo de habitação interfluvial, o deslocamento por caminhos florestais e a ênfase na caça-coleta associada à pesca e à agricultura de ciclo curto, os povos Naduhup e seu modo de vida ora são tomados como contraponto ou desvios ao padrão hegemônico, ora são simplesmente desconsiderados nas sínteses e nos modelos sociológicos. Seguindo esta perspectiva, acredita-se que enfocar não somente as referências discursivas às viagens, mas também as analogias entre os enunciados xamânicos e os movimentos dos viajantes em contextos mútuos de atuação possa contribuir para um melhor entendimento da prática do discurso xamânico dos Hupd'äh e de sua articulação ao "sistema regional de geografias xamânicas" (Cayón \& Chacon 2014:219).

\section{Discurso xamânico e mobilidade}

Os Hupd'äh habitam a região do Alto Rio Negro (AM) na fronteira entre o Brasil e a Colômbia. Suas comunidades situam-se às margens de igarapés da área interfluvial dos rios Tiquié e Papuri, afluentes da margem esquerda do rio Uaupés. Apesar de os dados demográficos oficiais estimarem a população num total de 1.500 indivíduos, um censo recente realizado pela FOIRN e o Instituto Socioambiental aponta para uma população em torno de 2.200 indivíduos distribuídos em aproximadamente 35 comunidades (Athias 2006; Epps 2008). O contato teve início com as frentes de colonização no século XVIII, mas foi apenas nas décadas de 1960 e 1970 que os missionários salesianos iniciaram atividades mais intensas visando à evangelização e à escolarização dos Hupd'äh. A língua hup pertence à família Naduhup (Makú) (Ramirez 2006; Epps 2008; Epps \& Bolaños 2017).

No xamanismo hupd'äh, a maior parte dos anciões domina as práticas de cura, proteção e agressão, sendo possível diferenciar os praticantes do xamanismo como /bi'íd hup îh/, "xamãs do sopro", /kầd hup îh/, "xamãs do banco", e/sấw hup îh/, "pajés". Possuindo um grau mais elevado de saberes xamânicos, os $/ s a ̂ ́ w /$ seriam o que geralmente a literatura etnográfica descreve como xamãs. Entretanto, deve ser ressaltada a importância do papel dos xamãs do banco e dos xamãs do sopro, que dominam grandes repertórios de benzimentos, práticas oníricas e rituais (ver Ramos 2013). 
A "linguagem dos benzimentos", /bi'id ìd/, que será abordada neste trabalho, constitui um dos principais gêneros discursivos do xamanismo hup. As práticas de cura e proteção são executadas por benzedores e xamãs que dominam essa forma de comunicação, marcadamente distinta da linguagem cotidiana pelo modo de enunciação (murmúrio e sopro), pelo paralelismo, e por complexas relações analógicas realizadas através de metáforas, metonímias, dentre outras figuras de linguagem. Nas exegeses desses benzimentos, os narradores descrevem seus deslocamentos pelos diferentes planos cósmicos, suas metamorfoses e interações com seres humanos e não humanos com a finalidade de curar ou proteger. ${ }^{4}$

Muitos dos anciões hup dominam grandes repertórios de benzimentos que variam em termos de detalhes e complexidade de acordo com a experiência e o conhecimento acumulados ao longo da vida. Todas as noites os senhores hup formam rodas para consumir coca e tabaco, conversar sobre mitos e encantamentos, e comentar sobre os itinerários percorridos durante o dia. Nas rodas noturnas, comentar sobre o desempenho na execução de um benzimento, contar partes de algum encantamento a alguém ou mesmo benzer pessoas compõem práticas dessa "linguagem dos benzimentos". Participando das rodas, os benzedores menos experientes poderão ouvir encantamentos contados como exegeses por senhores com mais conhecimento. Nessas exegeses, o xamã descreve suas viagens por diferentes ambientes e planos cósmicos, bem como suas interações com espíritos, animais, plantas que visam à proteção ou à cura de pessoas hup ou coletivos. Esse gênero do discurso xamânico hup assemelha-se aos descritos para outros grupos amazônicos da região (ver Reichel-Dolmatoff 1986; Buchillet 1992; Hill 1993; Lolli 2010), e também a gêneros de grupos de outras regiões (Chaumeil 1983; Seeger 1986; Townsley 1993; Whitehead $\&$ Wright 2004).

Como mostram Reichel-Dolmatoff (1978), Reid (1979), Buchillet (1983), os benzimentos realizam-se através de atos de fala (Austin 1962). Dependendo do objetivo do benzedor, o encantamento pode ser feito através de duas formas diferentes: os /ta' bi'íd/, "benzimentos de cercar", quando se quer proteger uma pessoa ou grupo, e os /pë' bi'íd/, “benzimentos de doença", quando o objetivo é o de curar um doente acometido por um mal. Ambas as formas contrastam com uma terceira denominada /döh/, "feitiço", atos de fala voltados a causar malefícios.

A execução dos encantamentos realiza-se através do murmúrio das ações xamânicas sopradas em um objeto físico de mediação, um veículo líquido, planta, cigarro etc. (Hugh-Jones 1995; Buchillet 1992). Ao enunciar um encantamento, palavras, sopro vital e corpo compõem um devir que 
permite ao benzedor movimentar-se pelo sociocosmos para acalmar a fúria dos seres que habitam outros mundos. Esse devir pessoa-sopro (sopro vital e pensamento), marcado por procedimentos de desconstrução e reconfiguração de si, realiza-se por meio de uma transdução para agir, mobilizando a energia do contínuo entre corpo e espírito, entre ego e alter (Lolli 2010:79; Ramos 2013:148; Viveiros de Castro 2008:89). Recebendo o sopro das palavras, o objeto efetua uma abdução da agência do benzedor para, posteriormente, realizar uma transdução que faz o encantamento agir na pessoa à medida que o demandante consome a planta, o cigarro, o líquido etc.

Assim como o objeto de arte estudado por Gell (1998), entendemos que o cigarro ou outro objeto xamanizado está imerso e age numa matriz social relacional. Seu índex material (visível, físico) permite a abdução da agência, já que é possível perceber o objeto xamanizado como uma entidade da qual se pode fazer inferência causal, inferência sobre as intenções ou capacidades de outras pessoas (1998:13). Enquanto instrumento da ação social, o objeto xamanizado abduz ao agir a partir de certa previsibilidade de eficácia (1998:14). Veículo abdutor e transdutor, o cigarro age no contínuo entre regimes corporais e perceptivos, transforma o modo de ação da viagem-palavra (sopro de ar) em um modo de ação de regeneração-cercamento (sopro) (Ramos 2013).

Sabendo que muitos dos elementos presentes nas exegeses de benzimentos se referem a plantas, animais, moradas ancestrais e diversos seres presentes nos percursos florestais, e que alguns itinerários conduzem os viajantes a grutas e morros onde ocorrem importantes práticas rituais de purificação, busca-se entender de que modo as experiências vividas durante viagens às serras que realizamos em 2012 e 2015 oferecem um paralelo à mobilidade xamânica posta em curso pelo ato de fala do senhor Ponciano Salustiano Ramos.

\section{Tiwit hamap bi'id - Benzimento dos caminhos}

O /tìwít hámap bi'id/, "benzimento dos caminhos", pode ser descrito como um encantamento xamânico para proteger os viajantes contra os possíveis ataques de cobras, cabas, Gentes-Árvore, Gentes-Sombra, onças e demais seres que possam ameaçar os andarilhos. A exegese que segue na Tabela 2 foi contada pelo sr. Ponciano Salustiano Ramos, benzedor e liderança tradicional da comunidade de/Tát Dëh/, "Taracuá Igarapé", no médio Tiquié. A gravação ocorreu em julho de 2011, na palhoça comunitária, logo após um de seus filhos, Samuel Brasil Monteiro, ter sido mordido no pé por 
uma jararaca. Na época, gravávamos e transcrevíamos as exegeses para a preparação de um livro de encantamentos que ajudaria os homens adultos no aprendizado das práticas xamânicas (tabelas 1 e 2). Samuel, o filho do narrador Ponciano, foi um dos colaboradores fundamentais na tradução final do benzimento.

\section{Tabela 1: Benzimento dos Caminhos}

\section{Tịwit hamap bi'ịd : Encantamento dos caminhos}

\section{Ponciano Ramos, gravado em Tat Dëh, 8 de julho de 2011.}

\begin{tabular}{|c|c|c|}
\hline 1 & Tæ̃ht̃y pinig. & História de cobra venenosa. \\
\hline $\begin{array}{l}2 \\
3\end{array}$ & $\begin{array}{l}\text { Bi'id ta' pinig. } \\
\text { Nup tiwit hitam d'äh. }\end{array}$ & $\begin{array}{l}\text { História de encantamento para cercar. } \\
\text { Esse é para ajudar nos caminhos. }\end{array}$ \\
\hline 4 & $\begin{array}{l}\text { Dög m’eh nih hohtëgët ãh sum bi’ } \\
\text { wi'th. }\end{array}$ & $\begin{array}{l}\text { Primeiro, eu faço-o ser ouvido na canoa da cobra } \\
\text { uirapixuna (Clelia rustica) }\end{array}$ \\
\hline 5 & Dög m'eh nih hohtëgët. & Na canoa da cobra uirapixuna. \\
\hline 6 & $\begin{array}{l}\text { Yup hohtëgan yet amd'ähät të tiw } \\
\text { m'e yí'. }\end{array}$ & $\begin{array}{l}\text { Para deitar essa canoa com vocês todos } \\
\text { dentro até onde vai o caminho. }\end{array}$ \\
\hline 7 & Dög m’eh nih hohtëg, & A canoa da cobra uirapixuna, \\
\hline 8 & sawi hohtëg, sawi tëg hohtëg, & $\begin{array}{l}\text { a canoa pau amarelo (Euxylophora sp.), } \\
\text { a canoa pau amarelo, }\end{array}$ \\
\hline 9 & hã̃ k'et w'ät hohtëg, & a canoa folha longa de louro (Ocotea sp.), \\
\hline 10 & hoho hã’ tëg hohtëg, & a canoa árvore louro-sapo, \\
\hline 11 & s'id tëg hohtëg. & a canoa árvore jacajaca. \\
\hline 12 & Dög m'eh nih hohtëgët & Com a canoa da cobra uirapixuna, \\
\hline 13 & ãh hohtëg niiy, & Eu possuo (essa) canoa, \\
\hline 14 & hup s'id b’ok ni hamawãh. & $\begin{array}{l}\text { Em posse da casca da árvore jacajaca }(\mathrm{eu}) \\
\text { sigo. }\end{array}$ \\
\hline 15 & $\begin{array}{l}\text { Yinihiy mah yup daha inan bahad } \\
\text { nihih. }\end{array}$ & $\begin{array}{l}\text { Assim, dizem, a cobra daha não aparece para } \\
\text { nós. }\end{array}$ \\
\hline 16 & Yup hohtëg k'ödan no yup... & Então, dizendo dentro dessa canoa... \\
\hline 17 & s'ibit b'öb b'ok ni ham ‘ëwan, & $\begin{array}{l}\text { para aquele que segue com a casca de tururi } \\
\text { (Sterculia sp.) ao redor de seus pés }\end{array}$ \\
\hline 18 & yup hohtëg k'ödan. & dentro dessa canoa. \\
\hline 19 & Noh k'ët ham yì' ta' të sõhan. & $\begin{array}{l}\text { Vai-se pisando e cercando todo o caminho até a } \\
\text { (casa) do inverno. }\end{array}$ \\
\hline $\begin{array}{l}20 \\
21\end{array}$ & $\begin{array}{l}\text { Ỹ̃ no yö', yuwan ỹ̃ no yö bay, } \\
\text { nih íb' b'e'et hita' yet ham d'ö'ay, } \\
\text { tĩhry n'an. }\end{array}$ & $\begin{array}{l}\text { Dito isso, tendo dita toda essa parte, } \\
\text { Eu estendo o pari para cercar a vida, (para } \\
\text { proteger contra) as cobras. }\end{array}$ \\
\hline 22 & [...] ib' b'e'et hidan hita' yö', & $\begin{array}{l}{[\ldots] \text { Tendo cercado para eles as suas vidas }} \\
\text { com pari, }\end{array}$ \\
\hline 23 & wed, hidan, wed no'ayah. & $\begin{array}{l}\text { a comida, eu ofereço comida a elas (as } \\
\text { cobras). }\end{array}$ \\
\hline 24 & Pũ'ũk, & Coca, \\
\hline 25 & tak pũ'ũk b’o', & a cuia de coca grudenta, \\
\hline 26 & pãhãy tak pũ'ũk b’o', & $\begin{array}{l}\text { a cuia de coca seiva de sorva (Couma } \\
\text { guianensis), }\end{array}$ \\
\hline 27 & mot tak pũ'ũk b'o'. & $\begin{array}{l}\text { a cuia de coca seiva de seringueira (Hevea } \\
s p .) \text {. }\end{array}$ \\
\hline 28 & Yuwut yup tĩhr̃y n'an, & Com isso, para essas cobras venenosas, \\
\hline
\end{tabular}




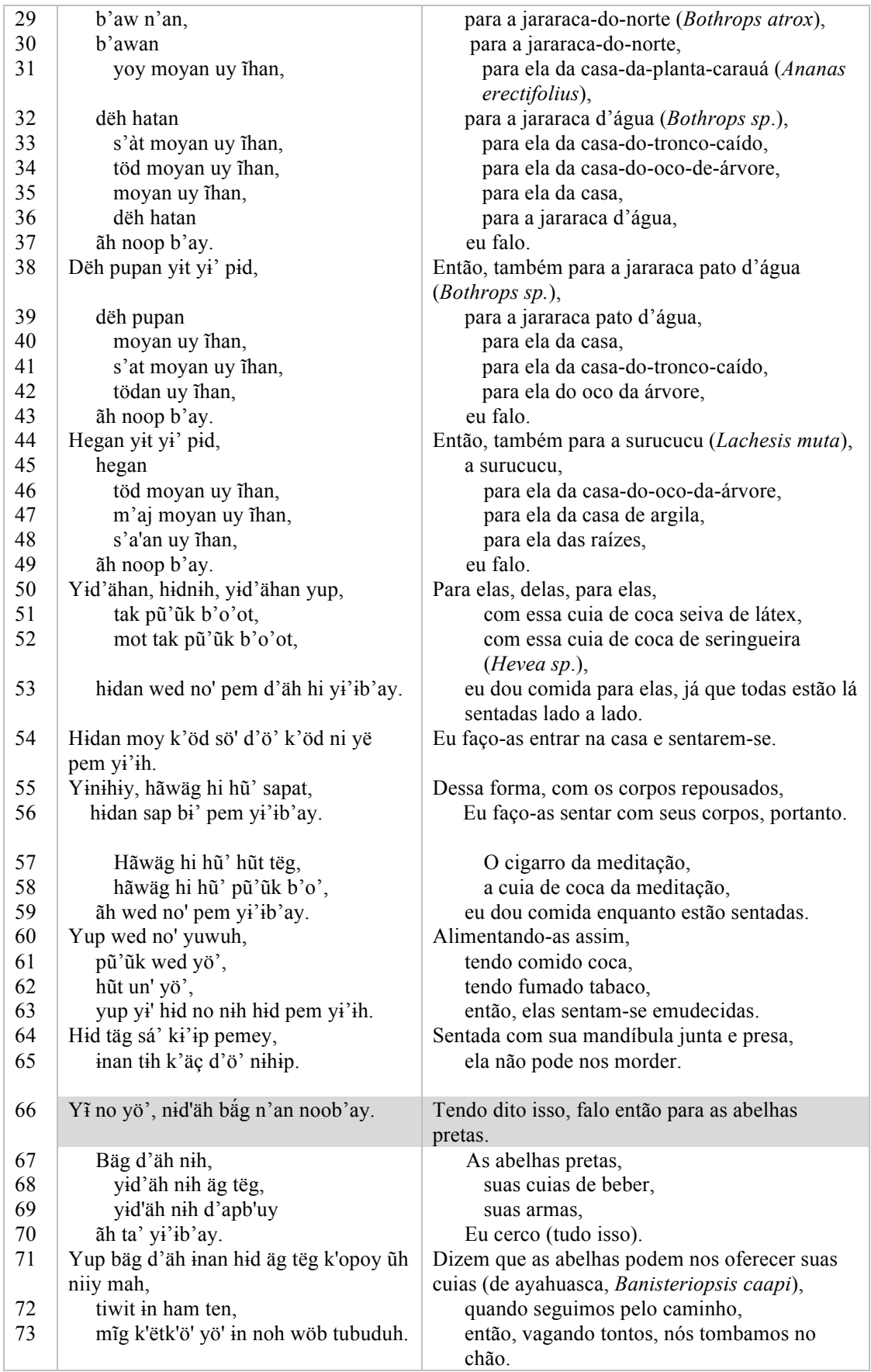


Hidnih hõp käk suk, hidnih d'apb'uy ãh no yi'ib'ay, yid'ähan b'ay, yup bäg n'an b'ayah.

Nup wiwíh n'an b'ay, yit yi’ pid.

B'aw n'an,

b'ab'aw n'an,

hidnih äg tëg,

ãh ta' yì'ib'ay noha,

hidnih d'apb'uy.

Yuwut yup inan äg tëg k'opoh.

Yup in äg na' hamawut

sadap noh yet yö'

in noh wöböh noha.

88

89

90

91

92

93

94

95

96

97

98

99

100

101

102

103

104

105

106

107

108

109

110

111 yisö', 112 pũ'ũk b'iyì' wed yö' tih pem yi'iy, noha'.

113

114

115

117

Ỹ̃ no yö’, tëgduh hup d'ähan noob'ayah.

Tëg duh hup d'ähan, mun moyan uy ĩhan, s'ug moyan uy îhan, b'ok moyan uy ĩhan, paç moyan uy ĩhan.

Tinih d'apb'uy, tinih d'apb'uy dö' ne yö’ pid,

moy k'öd sö' dö' k'öd ni yë k'et yi’'ib'ay.

Yid'äh nih, hidnih, tinih hũt säg, tinih d'apb'uy ni hũ' dö' ne yö' in yãhã' hi k'et yił'łb'ay.

S'ug moyan uy d'ähan b'ayah, mun moyan uy ĩhan, b'ok moyan uy ĩhan, eyet b'iyi̇' d'ö' ne yë k'et hũ' yił'ih.

Hùh moy k'öd sö' b'iyì hid n'an d'ö' köd pem yi' 'ih.

Yup pahap ãh no yi', pũ'ũk b'o', hidan hãwäg hi hũ' pũ'ũk b'o', hãwäg hi hũ' wed, wed no' yë pem yi'iy pid.

Yinihiy yup inan këy d'äh way nih

Ỹ̃ no yö’ b'ay hidnih kötöw tëg b'ay.

Hidnih kötöw tëg, nid'äh tëgd'uh hup d'äh nih kötöw tëg, b'atib' d'äh nih kötöw tëg,
Para seus anzóis de pesca, para suas armas eu falo, para elas, para essas abelhas pretas.

Para essas cabas wiwíh, (Eu falo) da mesma forma novamente.

Para as jararacas (Bothrops atrox), Para as cobras-cegas (Amphisbaena sp.), suas cuias de beber, eu cerco-as novamente, eu falo, (Eu cerco) suas armas.

Com isso (cuia) eles oferecem-nos bebida. Assim, quando seguimos como bêbados, tendo espatifado-nos no chão, nós continuamos caídos, eu falo.

Tendo falado dessa forma, eu falo então para a gente-árvore.

Para a gente-árvore, para ele da casa da caatinga, para ele da casa da floresta, para ele da casa de barro, para ele da casa de pedra.

Suas armas, tendo reunido todas as suas armas, (eu) faço-o entrar na casa e ficar em pé lá dentro.

Essas, suas (coisas), tendo reunido seus pedaços de tabaco, todas as suas armas,

nós as jogamos para baixo para permanecerem (dentro da casa).

Então, para esses da casa-da-floresta, para ele da casa-da-caatinga, para ele da casa-de-barro, reúno tudo para entrar e ficar em pé plenamente (dentro da casa).

Eu faço-os todos estarem sentados dentro da casa-da-cachoeira.

Então como menionei antes, a cuia de coca,

a cuia de coca da meditação deles, a comida (coca) da meditação deles, eu alimento-os conforme entram e sentam-se. Com isso, eles não saem de lá para observar-nos

tendo comido somente a coca ele permanece sentada, eu falo.

Tendo dito dessa forma, (eu volto-me) a seus bastões de dança.

Seus bastões de dança,

os bastões dessas gentes-árvore,

as coisas dessa (agressiva) gente-sombra, 


\begin{tabular}{|c|c|c|}
\hline 118 & $\begin{array}{l}\text { yid'äh nih yup kötöw tëg ãh ta' } \\
\text { yi't’b'ay. }\end{array}$ & então, eu cerco suas coisas. \\
\hline 119 & Yinih yup kötöw tëgët, & Desse modo, com esses bastões de dança, \\
\hline 120 & yinihip kötöw inan, & com isso eles espancam-nos, \\
\hline 121 & yup tiwit in ham ten kĩkt̃nt̃w ̃̄h. & $\begin{array}{l}\text { machucam-nos enquanto seguimos pelo } \\
\text { caminho. }\end{array}$ \\
\hline 122 & $\begin{array}{l}\text { inan hid siw'ipip, inan hid siw'ipip } \\
\text { in kĩkĩni’ îh noha'. }\end{array}$ & $\begin{array}{l}\text { Espancando-nos, escancando-nos eles } \\
\text { machucam-nos, eu falo. }\end{array}$ \\
\hline 123 & $\begin{array}{l}\text { Hidnih kötöw tëgët mah inan hid } \\
\text { kötöwöh, }\end{array}$ & Eles espancam-nos com seus bastões, dizem, \\
\hline 124 & sãy tëg kötöw tëg, & seus bastões de imbaúba sãy (Cecropia \\
\hline 5 & wag tëg kötöw tëg b'ay, & $s p)$. \\
\hline 126 & yẽn'ihan ãh ta' hũ' yi' ih noha'. & $\begin{array}{l}\text { seus bastões de imbaúba wag (Cecropia } \\
\text { sciadophylla?), } \\
\text { eu cerco completamente todos esses, eu falo. }\end{array}$ \\
\hline 127 & $\begin{array}{l}\text { Hidnih moy k'öd sö' pid yãhã' yë } \\
\text { k'ët yì'ih. }\end{array}$ & $\begin{array}{l}\text { Eu jogo para baixo (os bastões) para entrar e } \\
\text { ficar em pé dentro da casa deles. }\end{array}$ \\
\hline 128 & Yup ãh no ham yi’ yö’ të! & Tendo seguido e dito tudo isso até.. \\
\hline 129 & yup ãh no ham yí yö’ të! & tendo ido e dito tudo isso até..., \\
\hline 30 & moy widham tëëway, & eu chego a uma casa, \\
\hline 31 & sãp hayam widham tëëway, & eu chego em outra comunidade, \\
\hline 132 & hũt tõh n'an ãh no'op b'ayah. & agora eu falo para as lagartas do tabaco. \\
\hline 133 & Hũt tõh meh nih, & Das pequenas lagartas, \\
\hline 134 & yid'äh nih tiwit, ãh yëay yup, & Pelos seus caminhos, eu entro, \\
\hline 135 & sãp hayamat ãh yëëwayah. & eu adentro outra comunidade. \\
\hline 136 & Hũt tõh meh nih, & Das pequenas lagartas, \\
\hline 137 & tinih tiwit yë yö' b'ay, & Tendo adentrado por seus caminhos, \\
\hline 138 & hayam nomih tẽh nih, & Do pequeno chefe da comunidade, \\
\hline 139 & yuwut tinih ib' käd buysö & com isso e sobre seu banco da vida, \\
\hline 140 & $\begin{array}{l}\text { ãh hup hãwäg hup yäd yë k'ët yì'th } \\
\text { noha'. }\end{array}$ & $\begin{array}{l}\text { eu entro e fico em pé, oculto minha pessoa- } \\
\text { sopro (espírito). }\end{array}$ \\
\hline 141 & Hup hũt tëg ni ë d'äh, & Estes que possuíram o cigarro na origem, \\
\hline 142 & hup käd ni yë pem yì' ih noha'. & $\begin{array}{l}\text { em posse de seus bancos (eles) entram e } \\
\text { sentam-se, eu falo. }\end{array}$ \\
\hline 143 & $\begin{array}{l}\text { Yuwut yë pem yö' ãh way yi'ib'ay } \\
\text { hay'ah sö'. }\end{array}$ & Tendo entrado e sentado lá, eu saio. \\
\hline 144 & Yớh sid meh d'äh nih, & $\begin{array}{l}\text { Os pequenos muçuns (enguia-d'água-doce) } \\
\text { sid (Symbranchus marmoratus), }\end{array}$ \\
\hline 145 & hidnih sapat. & seus corpos. \\
\hline 146 & Ow meh d'äh nih, & Os pequenos lagartos, \\
\hline 147 & hidnih sapat, & com seus corpos, \\
\hline 148 & hup sap ni yö', way k'ëtëb'ay noha'. & $\begin{array}{l}\text { depois de ter seus corpos (eu) saio e fico em } \\
\text { pé, eu falo. }\end{array}$ \\
\hline 149 & Ow d'äh nih sapat, & Com os corpos dos lagartos pequenos, \\
\hline 15 & bö meh d'äh nih sapat, & $\begin{array}{l}\text { com os corpos dos tico-ticos (Zonotrichia } \\
\text { capensis), }\end{array}$ \\
\hline 151 & síw meh d'äh nih sapat, & $\begin{array}{l}\text { com os corpos dos curiós (Sporophila } \\
\text { angolensis), }\end{array}$ \\
\hline 152 & hup sap ni way k'ët yì'th. & tendo seus corpos (eu) saio e fico em pé. \\
\hline $\begin{array}{l}153 \\
154\end{array}$ & $\begin{array}{l}\text { Yuwut way k'ët yö' b'ay, } \\
\text { yõh sid d'äh sö' d'öb d'ö' b'ay. }\end{array}$ & $\begin{array}{l}\text { Depois de sair e sentar lá, } \\
\text { (eu) vou para baixo, para a água para onde os } \\
\text { muçuns sitd estão. }\end{array}$ \\
\hline 155 & Yõh sidit, & Com o muçum sid, \\
\hline
\end{tabular}




\begin{tabular}{|c|c|c|}
\hline 156 & yõh s & \\
\hline 157 & yuwut tinih sa & , com seu \\
\hline 158 & yuwut tinih hũt & com isso, com \\
\hline 159 & yuwut tinih d'apb'uy, & com isso, com suas armas, \\
\hline 160 & hup d'apb'uy ni & em posse de suas armas, \\
\hline 161 & yuwut tinih hi & com isso, com seu cigarro, \\
\hline 162 & hũ' tëg ni yup, & possuindo o cigarro, \\
\hline 163 & ãh hup sap ni yë k'ët yił'ih, & em posse de seu corpo, eu entro e fico em pé. \\
\hline 164 & $\begin{array}{l}\text { Tinih moy k'öd b'ay, yõh sid nih } \\
\text { b'ay. }\end{array}$ & Dentro de sua casa, do muçum sid. \\
\hline 165 & Yõh sidit yë yö' b'ay, yõhõt b'ay. & $\begin{array}{l}\text { Tendo entrado onde o muçum sìd está, com o } \\
\text { enguia muçum. }\end{array}$ \\
\hline 166 & Yõhõt yë’ k'ët yö' b'ay yup, & $\begin{array}{l}\text { Tendo entrado e sentado com o muçum sid, } \\
\text { Eu retorno e saio }\end{array}$ \\
\hline $\begin{array}{l}167 \\
168\end{array}$ & $\begin{array}{l}\text { hay'ah sö’ ãh way 'ayab'ay, } \\
\text { s'ug sö' b'ay. }\end{array}$ & Para a floresta. \\
\hline 169 & B'ib'ib' mehet b'ay. & (Então) novamente com o esquilo cinza pequeno. \\
\hline 170 & B'ib'ib' meh r & Do e \\
\hline 171 & yuwut tinih hũ & com isso, col \\
\hline 172 & yuwut tinih moy k'öd, & com isso, dentro de sua casa, \\
\hline 173 & moy k'öd ni yë' k'et yi’’ib'ay. & (eu) eu entro e fico em pé dentro da casa. \\
\hline 174 & Ỹ̃ no yö’, & Tendo dito isso, \\
\hline 175 & b'ib'ib' mehet no yö', & tendo falado para o esquilo cinza pequeno, \\
\hline 176 & woman b'ay. & eu falo para o esquilo vermelho, \\
\hline 177 & Womot, wom nih, & com o esquilo vermelho, do esquilo vermelho, \\
\hline 178 & yuwut tinih hũt tëg, & com isso, seu cigarro, \\
\hline 179 & yuwut tinih moy k'öd, & com isso, dentro de sua casa, \\
\hline 180 & hup moy k'öd ni yë' k'ët y & $\begin{array}{l}\text { para estar dentro da casa (eu) entro e fico em } \\
\text { pé. }\end{array}$ \\
\hline 181 & Yuwan no yö', & Tendo dito isso, \\
\hline 182 & in no ten $\mathrm{me}$ & $\begin{array}{l}\text { quando nós falamos, dizem, para nós, } \\
\text { doença, }\end{array}$ \\
\hline 183 & $\begin{array}{l}\text { sãp hayamat in widham pë' kay' } \\
\text { nih noha'. }\end{array}$ & $\begin{array}{l}\text { quando nós chegamos a outra comunidade, } \\
\text { para que a doença não nos envolva, eu } \\
\text { falo. }\end{array}$ \\
\hline 184 & Sãp hayamat inan këy hipãh nihih. & $\begin{array}{l}\text { Na outra comunidade, não nos reconhecem } \\
\text { (as doenças). }\end{array}$ \\
\hline 185 & $\begin{array}{l}\text { Yinih yö', yup wom d'äh d'äh way k'ët } \\
\text { yö', }\end{array}$ & $\begin{array}{l}\text { Então, após ter ordenado ao esquilo vermelho } \\
\text { para sair e ficar em pé, }\end{array}$ \\
\hline 186 & ãh widyë d'ö' kädwayab'ay, yikan. & $\begin{array}{l}\text { eu chego, entro e faço com que saiam rápido } \\
\text { de lá. }\end{array}$ \\
\hline 187 & S'ug sö' ãh ham 'ayah. & Eu sigo e retorno da floresta. \\
\hline 188 & Ya'am tẽhẽt, & Com a jaguatirica (Leopardus sp.), \\
\hline 189 & nid'ähät, did ya'amat, & Com esse, com o jaguar do tronco de \\
\hline 190 & ãh ham d'ö' b'ayah noha'. & $\begin{array}{l}\text { árvore, } \\
\text { eu vou novamente para pegar (eles), eu falo. }\end{array}$ \\
\hline 191 & Yit ham d'ö' yö' b'ay, & Assim, tendo seguido e pego, \\
\hline 192 & yit ham yö', yid'äh wom d'ähät, & $\begin{array}{l}\text { Tendo ido, tendo seguido com esses esquilos } \\
\text { vermelhos, }\end{array}$ \\
\hline 193 & ya'am & Com os jaguares, até! \\
\hline 194 & Yuwan yup hãyãt, kög-pupu' yõh dëh. & $\begin{array}{l}\text { (Eu chego) nessa água pura do maracujá } \\
\text { (Passiflora acuminata). }\end{array}$ \\
\hline
\end{tabular}




\begin{tabular}{|c|c|c|}
\hline 195 & Kög-pupu' yõh dëh yagat, & $\begin{array}{l}\text { Com a rede do maracujá, } \\
\text { (eu) possuo a rede, entro e deito-me, }\end{array}$ \\
\hline 196 & hup yag ni yë k'ã'ayah, & dentro da flor do maracujá, \\
\hline $\begin{array}{l}197 \\
198\end{array}$ & $\begin{array}{l}\text { kög-pupu' s'o’ k'ödan } \\
\text { hup yag ni yë k'ã' yi'ayah. }\end{array}$ & $\begin{array}{l}\text { (eu) possuo a rede e entro para deitar } \\
\text { (dentro dela). }\end{array}$ \\
\hline 199 & Hup hãwäg hup yäd yë k'ã'yi'ayah. & $\begin{array}{l}\text { Ocultando minha pessoa-sopro (espírito), (eu) } \\
\text { entro para deitar (dentro dela). }\end{array}$ \\
\hline $\begin{array}{l}200 \\
201\end{array}$ & $\begin{array}{l}\text { Yag pũp s'o' k'öd, } \\
{[\ldots] \text { hup hãwäg yag ni yë' k'ã' yì }} \\
\text { ayah. }\end{array}$ & $\begin{array}{l}\text { Na rede dentro da flor, } \\
\text { então (minha) pessoa-sopro possui a rede e } \\
\text { entra para deitar-se (dentro dela). }\end{array}$ \\
\hline 202 & Bahad nihr̃p, hũt tëgët, & oculto, com o cigarro, \\
\hline 203 & bahad nihip yagat, & com a rede de ocultar, \\
\hline 204 & hup yag ni yë k'ã' yi’ ayah. & $\begin{array}{l}\text { (eu) possuo a rede e entro para deitar (dentro } \\
\text { dela). }\end{array}$ \\
\hline 205 & 'Eyet tiwit ham k'ö'an 'uy yuwuh. & $\begin{array}{l}\text { Esse é (o encantamento) para aqueles que vão } \\
\text { juntos pelo caminho. }\end{array}$ \\
\hline 206 & Yit tih ham k'ëtëh, yit tih tohooh. & $\begin{array}{l}\text { Esse (encantamento) segue acima até aqui, e } \\
\text { dessa forma ele termina. }\end{array}$ \\
\hline 207 & Tiwit ham d'äh in hup bi'id n'th, & $\begin{array}{l}\text { (Esse é) para nós o encantamento para aquele } \\
\text { que segue pelo caminho, }\end{array}$ \\
\hline 209 & $\begin{array}{l}\text { sãp hayamat ham d'äh in hup bi'id } \\
\text { n'th. }\end{array}$ & $\begin{array}{l}\text { (esse é) para nós protegermos aqueles que } \\
\text { seguem para outra comunidades. }\end{array}$ \\
\hline 210 & Yit tih tohooh. & E assim termina. \\
\hline
\end{tabular}




\section{Tabela 2: Sequência de movimentos e ações do benzimento dos caminhos Sequência de movimentos e ações do benzimento dos caminhos (Ver exe- gese transcrita e traduzida abaixo)}

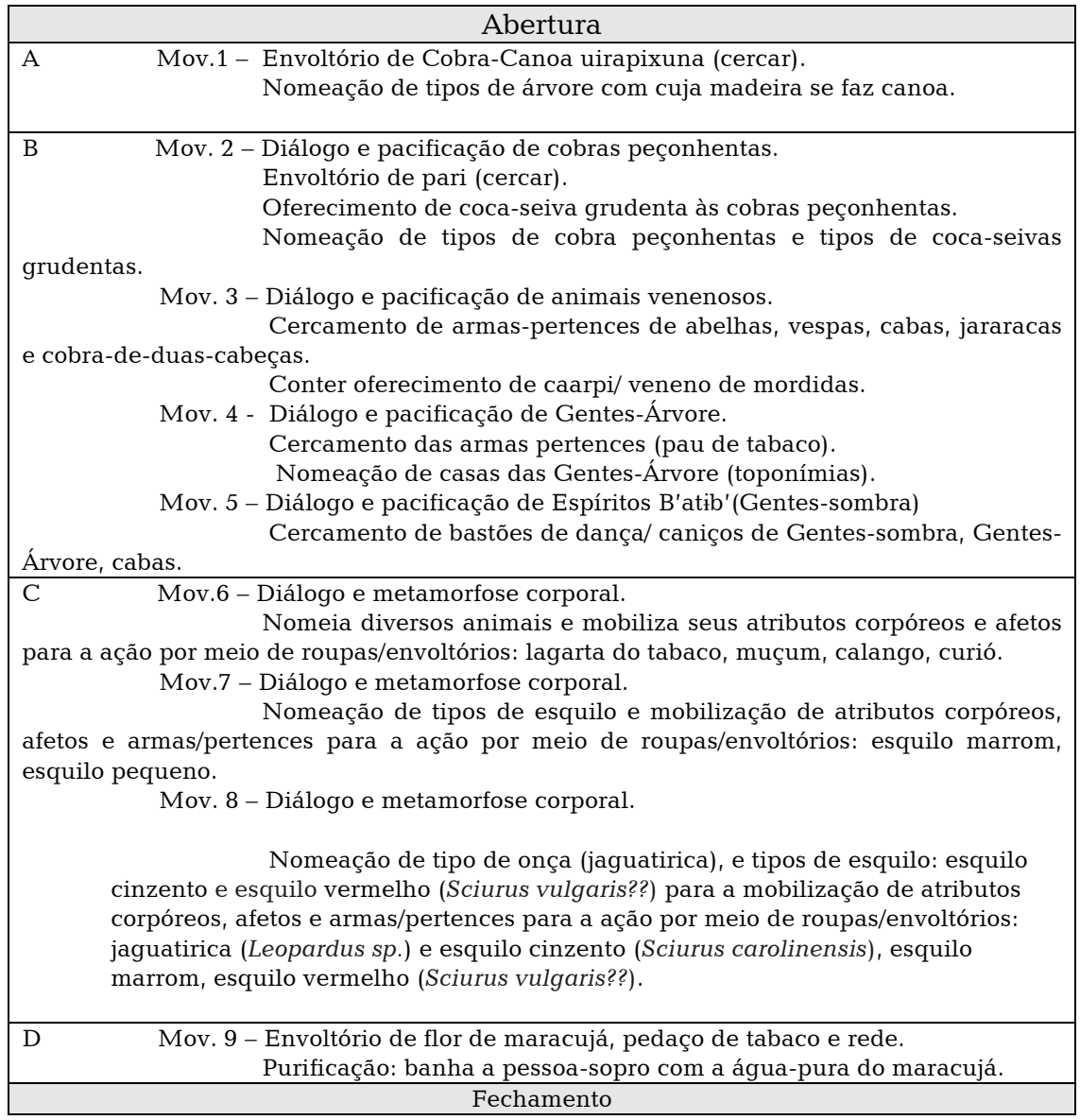

As etapas de transcrição, tradução e análise foram realizadas em 2012 com a assessoria de Angélico Brasil Monteiro e do professor Evaldo Monteiro Pires, que sempre consultavam os benzedores para esclarecer dúvidas durante as rodas de coca (Ponciano Salustiano Ramos, João Brasil, Miguel Andrade Oliveira, José Salustiano e Vicente Salustiano Monteiro). A tradução passou ainda por mais duas etapas com uma revisão feita por Ramos e Epps em 2015, e uma última realizada por Epps e Samuel em julho de 2016.

O texto da exegese estrutura-se a partir de uma sequência de /hàm/, "movimentos", "idas" ou "viagens", deslocamentos do benzedor como pessoa-sopro para diferentes lugares do sociocosmos. Tais lugares são 
nomeados muitas vezes como /Mòy/, "Casa/Maloca/Morada", ou /S'áh/, "terras/ mundos" (ver "casas cósmicas" em Reid 1979, Reichel-Dolmatoff 1986:105; e "planos-casa" em Lolli 2010:87). São campos relacionais dominados pelo ponto de vista de Espíritos, Onças, Cobras, dentre outros. Através da enunciação contínua e cadenciada das palavras, entrecortada por sopros que fazem as palavras-movimentos penetrarem os objetos para xamanizá-los, o benzedor desloca-se e posiciona-se nesses campos relacionais para interações e diálogos transespecíficos (Viveiros de Castro 2002, cap. 7:358). Nesses encontros, o benzedor visa acalmar seu interlocutor ou metamorfosear-se corporalmente mobilizando para si as potências instrumentais dos / sáp/, "corpos" de outros seres.

Cada conclusão de deslocamento do xamã é descrita como a chegada a uma morada. Sua chegada e a postura ereta assumida contribuem para a criação do contexto enunciativo próprio para que o xamã /no-/, "fale", para os moradores, pacificando-os ao fazer com que, através de sua palavra, baixem ou guardem suas armas, entrem, sentem-se ou comam, abandonando posturas agressivas contra os viajantes para assumirem posturas contemplativas e de interlocução entre si. Realizam-se assim diálogos transespecíficos por meio dos quais o xamã age entre perspectivas posicionando-se em campos relacionais dominados por ontologias outras (Viveiros de Castro 2002:358)

O enunciador menciona/nomeia cada um dos objetos ou seres, realizando sequências recorrentes ao longo da exegese. Vai contribuindo, assim, para uma descrição da morada desses seres e da perspectiva imanente a esses planos cósmicos. Ao nomear os instrumentos e pertences de cada interlocutor, o xamã externa sua ciência das armas, objetos que foram dados a cada um dos seres por demiurgos em eventos míticos. É por meio dessas /d'ab'ùy tëg/, "armas", ou /hếh/, "coisas" ou "pertences", que os interlocutores agem mobilizando para si potências destrutivas, criativas ou regenerativas. Como sugere Viveiros de Castro (1998), nomear é externar. O xamã age assim em relação às afecções desses seres, ou seja, sobre as "forças" ou "talentos" adquiridos e refinados ao longo do tempo (Viveiros de Castro 2002:380). Assim, o ato de /no-/, "falar para", seguido do ato de nomear geram discursivamente o efeito de presença, a interação do xamã com os moradores de uma dada Casa, a separação dos sujeitos (interlocutores) de suas armas/pertences primordiais (pacificação) (Buchillet 1992; Hugh-Jones 1995).

Pensando com Dell Hymes (1981) e Tedlock (1983), é possível dizer que cada movimento se organiza por meio de linhas que se juntam formando grupos ou "versos". No que diz respeito à performance de enunciação das exegeses de encantamento, a prosódia relativa à estrutura de linhas e versos inclui a entonação ascendente-descendente e as pausas. O texto das exegeses 
é geralmente enunciado em situações de interlocução entre benzedores nas rodas de coca, em diálogos com jovens que tenham interesse em aprender esta arte verbal e, mais recentemente, nas entrevistas de gravação sonora realizadas por pesquisadores. Assim, há uma intenção didática predominante nos encantamentos, ancorada em uma assimetria de conhecimentos entre aquele que/käsät-ham-/ (lit. "vai na frente") "guia" - "lidera", a enunciação e aquele que/wi'-/, "ouve" - havendo um sentido de "seguir a fala" expresso pela repetição de palavras ou frases sempre que o enunciador conclui uma linha.

É possível perceber "enquadres introdutórios" (frames), comentários iniciais que fazem referência a episódios míticos ou a práticas rituais (Urban 2000:79). No "benzimento dos caminhos", esse traço pode ser visualizado logo na primeira linha: "Tťrtýy pintig, bi'id tà' piníg, nup tìwít hitàm d'äh. / História de jararaca, narrativa de benzimento para cercar, essa ajuda (os andarilhos) no caminho". O enunciador intitula, classifica o encantamento e precisa a intenção de eficácia na proteção dos andarilhos, dotando o enquadre de apresentação de um forte caráter metadiscursivo (Urban 2000:79).

Como modos de ação verbais, as exegeses e as enunciações de encantamentos são conjuntos composicionais através dos quais o benzedor agrega ou subtrai movimentos que podem, eles mesmos, em dadas situações, ser executados como encantamentos completos. O "benzimento dos caminhos", por exemplo, exige uma avaliação estratégica e projetiva do enunciador, procurando antecipar as possíveis ameaças aos andarilhos. Quando considera que sua viagem-palavra permitiu atenuar as potências agressivas de seus interlocutores cósmicos, o benzedor retorna e concentra novamente sua pessoa-sopro. Nesse momento, é preciso concluir o enunciado-ação /hisu'-/, "fechando", do benzimento com sentenças de finalização, como /Yìt tìh töhööh/, "Aqui termina", que acompanham o gesto de /hik'ët-/, "pisar".

O gesto de "pisar" pode ou não ser mencionado na exegese, mas deve sempre ser realizado pelo xamã por evidenciar sua chegada, sua aterrissagem com a postura de firmar com precisão os pés na terra, em "minha terra", /ní s'áh/, um mundo onde predomina o ponto de vista hup. Assim, concebida como uma "viagem", o itinerário xamânico configura-se também como um deslocamento aéreo, um "voo xamânico" (ver Reichel-Dolmatoff 1978). O "voo" e cada "movimento" constituem uma rede de caminhos-ação que, segundo Samuel Brasil Monteiro, é como uma /hõp sèg/, "rede de pesca", semelhante às usadas para a pesca, ou a uma/suh yàg/, uma "teia" ou "tela" igual àquela que segura a pessoa-sopro de cada um no peito. Com o ato de "pisar a terra", o xamã amarra os caminhos-ação de sua viagem e "cerca", protegendo os andarilhos ou aquele que precisa de sua proteção para realizar um percurso florestal. 


\section{Viagens aos lugares sagrados}

Passamos agora a descrever duas viagens a lugares sagrados realizadas em 2012 e em 2015 por um mesmo itinerário que passa por antigos aldeamentos e leva aos morros de /Nik-Hú Pàç/, "Serra de Nik-Hũ"; /D'ók Pàç/, "Serra do Acarapuru"; /B'ö' Pàç/, "Serra do Tucunaré"; e /Hũyáw Pàç/, "Serra da Paca". O benzimento dos caminhos foi executado nas duas ocasiões para a proteção dos grupos de viajantes formados por jovens, adultos e anciões. Em 2012, foi o próprio sr. Ponciano quem soprou o cigarro e envolveu todos com a pele fria da Cobra-Canoa Uirapixuna. Em 2015, Ponciano encontrava-se em Santa Isabel e não pôde nos acompanhar. Por isso, Manoel Barbosa (2015) executou a ação xamânica logo após nosso primeiro dia de percurso. Ambas as viagens contribuíram imensamente para a tradução e o entendimento do "benzimento dos caminhos", já que a exegese se relaciona diretamente com elementos presentes no cotidiano das caminhadas florestais e, principalmente, com aqueles que possam representar riscos aos viajantes.

Em 2012, um dos temas recorrentes das conversas nas rodas de coca era o fechamento dos caminhos que levavam às aldeias antigas e aos morros (lugares sagrados). Nos momentos iniciais dos encontros, os jovens manifestavam interesse em viajar com os senhores hup para conhecer os cenários de tantas histórias e mitos. A participação de Ramos e sua vontade de juntar-se ao grupo de viajantes foram certamente incentivos decisivos para que as viagens entre anciões e jovens, tão comuns no passado (Reid 1979:150), fossem retomadas. Após um longo período de chuvas, um grupo formado por seis jovens e dois anciões decidiu rumar para a região das cabeceiras, reabrindo os antigos caminhos. A viagem total foi realizada em quatro dias de intensa caminhada. Levamos dois dias para chegar até a primeira serra, /D'ók Pàç/. Visitamos ainda os morros /Nik-Hû́ Pàç/, /B'ö' Pàç/, e a /Huỹáw-Pàç/. Durante todo o trajeto foram feitas marcações com o GPS, anotações no caderno de campo e fotos de paisagens. Ao final da tarde, montávamos acampamento à beira de igarapés, e nos dedicávamos à pesca e à caça que garantiam a alimentação do grupo.

Já em 2015, a incursão aos morros foi motivada pela realização das atividades de desenvolvimento do Plano de Gestão Territorial e Ambiental Hupd'äh (PGTA-HUP). ${ }^{6}$ O mapeamento participativo dos caminhos, dos aldeamentos antigos e dos morros foi tomado como um dos objetivos estratégicos do plano após reuniões da comunidade com o sr. Américo Socot, representante dos Hupd'äh da Funai, ${ }^{7}$ e com o assessor técnico, Danilo Ramos. A crescente ameaça de exploração dessas regiões por empresas mineradoras ou por associações de mineradores indígenas de outras 
etnias sem o diálogo com os Hupd'äh apontou a importância de abrir os caminhos, registrar espaços e pontos relevantes para a memória social, a cosmografia e o manejo ambiental de modo georreferenciado. Além disso, anciões e adultos sinalizavam a importância de os jovens conhecerem tais caminhos e destinos, apropriando-se de referências fundamentais à proteção política e xamânica de suas terras. A observação de plantas, a passagem por áreas de caça e coleta e a interação com espíritos e animais ao longo do percurso foram vistas também como relevantes para o aprendizado de encantamentos e a aquisição de habilidades xamânicas. Não por acaso, o "etnomapeamento" foi traduzido pelas lideranças hup como /S'áh tà'/, "cercamento a terra", numa ação que, através dos itinerários, criava uma proteção xamânica para a terra hup.

Os chamados /húp tìw/, "caminhos de hup", iniciam-se como continuações dos trajetos para as roças, que vão se estreitando aos poucos até formarem trilhas fechadas que se diferenciam sutilmente da densa mata. Seguindo esses percursos, as pessoas se dirigem diariamente aos igarapés para a pesca, às roças para o cultivo, deslocam-se para outras aldeias e seguem os rastros de animais. Mas em alguns momentos os andarilhos realizam viagens para os morros situados nas cabeceiras, como as que fizemos em 2012 e 2015 rumo a aldeamentos antigos - /Mòy-Höd/, "Moradas Antigas" - onde seus antepassados habitaram antes de viverem na grande aldeia de /Tát Dëh/, e às /Pàç Moy/, "Casas de Pedra", locais de morada de ancestrais e também de realização de práticas rituais. Chegamos assim a paisagens míticas, lugares impregnados pela ação de ancestrais e demiurgos cujos feitos são narrados através das /piníg/, "mitos/histórias" (Wright 2013).

Muitos dos caminhos que se iniciam nas imediações da aldeia logo cruzam os chamados /tìw pög/, "caminhos grandes", que levam a outras aldeias ou mesmo aos povoados-cidades de Iauareté e Pari-Cachoeira. Na viagem de 2012, Ponciano indicou para os rapazes as seguintes rotas que cruzávamos: /Yàk Dëh Tìw/, "caminho do Arara-Igarapé"; /Hó Dëh Tìw/, "caminho do Igarapé-Fígado"; /Tìw Dööy/, "caminho vermelho"; /Wähäd Tìw/, "caminho dos antigos" que leva para o Morro da Anta; /Iraiti Tìw/, "caminho para Iraiti". Já em 2015, José apontou o /Iraiti Tìw/, “caminho de Iraiti" (comunidade miriti-tapuya no Médio Tiquié), /Yàk Dëh Tìw/, "caminho do Arara-Igarapé" (morro e antigo aldeamento). Dada a intensa circulação de pessoas, esses grandes caminhos que se mantêm abertos podem ser tomados como semelhantes às rotas arawak (rotas de Kuwai) descritas pela literatura (Vidal 1999, 2000; Vidal \& Zucchi 2000; Hill 2011; Wright 2013).

Assim como as rotas arawak abertas pelo demiurgo Kuwai, as rotas hup, que integram essa região de lugares sagrados e aldeamentos antigos visitada 
em 2012 e 2015, foram abertas por um ancestral, /Yàk Hib'àh Tẽh-ĩh/, "Ancestral Arara". Como contou Ponciano, saindo de /Pìj Dëh/, "Cabari Igarapé", ele abriu os caminhos para fazer sua /mòy/, "casa", em /Yàk Dëh K'ëtyoh/, "cabeceira do Arara-Igarapé". De lá rumou para/Wõh Dëh/, "Breu-Igarapé", e concluiu sua viagem de abertura de caminhos no Iraiti (Médio Tiquié). Diferentes das rotas arawak e tukano que margeiam os grandes rios locais, essas rotas hup integram a região através de percursos delineados pelas planícies interfluviais dos rios Tiquié e Papuri, margeando os estreitos igarapés.

Tendo sempre como referência uma rota, as trilhas que levam às aldeias antigas e aos morros (lugares sagrados) são geralmente estreitas e fechadas. São designadas /tìw täm/, "caminhos cerrados", ${ }^{8}$ que precisam ser abertos com o corte dos terçados daqueles que vão à frente. Fechados, esses percursos impedem a ampla circulação de pessoas e agem como no princípio xamânico do cercar /ta'-/, protegendo as paisagens míticas e os lugares de memória. Para circular por esses trajetos é preciso estar com alguém que conheça a rota para que o grupo possa reabri-la. /Tìw hipãh-/, "saber o caminho", não diz respeito a conhecer um modo de conectar pontos, mas sim a ir revelando as linhas que envolvem lugares onde o guia cresceu, caçou, colheu frutos, enterrou parentes. Entendemos que as viagens aos morros se delineiam através do envolvimento mútuo, situado e atento, a partir do qual os rapazes tomam como referência a "linguagem dos benzimentos", as narrativas e os atos de mostrar dos mais velhos para situarem-se nos campos relacionais dos encontros interespecíficos, cuja inteligibilidade e cujo posicionamento envolvem uma complexa percepção dos pontos de vista-sujeito de animais, plantas e espíritos situados a partir de seus mundos-casas-corpos.

\section{Caminhos florestais e itinerários xamânicos}

Seguindo no paralelo entre o "benzimento dos caminhos" e as viagens realizadas a lugares sagrados de 2012 e 2015, descreveremos agora alguns traços marcantes dos caminhos, como os encontros com animais e espíritos na passagem por suas moradas (/mòy/) e a nomeação de plantas e toponímias, na busca por entender melhor como, por meio da retórica ambulatória (De Certeau 2011:167-168) do discurso xamânico e da socialidade dos itinerários florestais, situa-se um processo de educação da atenção para a complexa deixis cosmológica, que vai evidenciando, de modo indexical, as perspectivas e os mundos atravessados pelos caminhos (Viveiros de Castro 1998). 
Em 2015, no início da viagem, paramos para descansar nas imediações da /H’̀’ Mun/, "Caatinga da escrita", local que, segundo José, era rico num tipo de folha / $h \grave{t}^{\prime} \mathrm{k}^{\prime} \mathrm{et} / \mathrm{n}$ a qual os ancestrais escreviam e inscreviam os padrões gráficos de bancos e cerâmicas. Os rapazes levavam cadernos e canetas para fazerem anotações e desenharem mapas a partir dos percursos e da história dos mais velhos. A narrativa de José sobre a "caatinga da escrita" estabelecia uma continuidade entre os jovens caminhantes e os ancestrais que escreviam em folhas de plantas e objetos rituais. A escrita dos Hupd'äh era, assim, anterior ao PGTA, aos "brancos", e era praticada pelos rapazes a partir do processo de educação da atenção possibilitado pelo caminho (Ingold 2000, cap. 8:146). Como poderá ser percebido, o aprendizado surge a partir da trajetória da atenção dos viajantes para suas próprias ações e para aquelas de seus interlocutores interespecíficos enquanto abrem o caminho.

Ao contrário das rotas, que oferecem facilidade no trânsito, os /s'ùgút tìw/, "caminhos da floresta", precisam ser feitos. Aptos a andar pela mata e a caçar, os rapazes aprendem a /tìw bi'-/, "fazer o caminho", à medida que vão sendo inseridos pelos guias em uma região de memórias e narrativas. Esse princípio é semelhante ao modo como o benzedor delineia seu itinerário ao executar um encantamento. Análogos aos caminhos da mata, os /hàm/, "movimentos", exigem uma interpretação da situação, da pessoa ou do coletivo que deve ser curado ou protegido, e das ameaças ou ações patogênicas que poderão causar ou causaram uma doença ou mal.

A cada execução, o "caminho" do benzimento é igualmente "feito" por palavras, sopros e deslocamentos do xamã. No "encantamento dos caminhos", o xamã mobiliza (Mov.1) as potências corporais da Cobra-Uirapixuna e cria uma "cobra-caminho-canoa". Soprando a fumaça do cigarro em seus corpos no início da viagem, os andarilhos projetam possíveis encontros perigosos e se protegem deles. O benzedor "faz o caminho" antes mesmo de começar a guiar a sua abertura, e faz o grupo aparecer aos seres antagônicos como uma predadora-itinerário-veículo. Proteger-se e agir projetivamente sobre o caminho florestal antes de iniciar sua feitura, deslocar-se pelo sociocosmos de modo imanente e simultâneo à viagem por terra podem ser vistos como habilidades iniciais que os jovens caminhantes aprendem e que são chave para futuramente "abrirem caminhos" e "soprarem o benzimento dos caminhos".

Na viagem de 2015, ao apontar a /dò̀g tëg/, "árvore uirapixuna", Américo disse sobre sua importância para a cerimônia ritual do Dabucuri, e de seu uso para a alimentação de inambus, tucanos, preguiças e peixes. Outras árvores que foram indicadas e comentadas pelo jovem Mauro foram as paxiúbas, /himún tëg/; uma delas, boa para fazer jiraus e barcos de brinquedo, e a outra com a qual se fazem flautas jurupari. A árvore uirapixuna é também 
uma /Mòy/, "Casa", das muçuranas, que são correntemente encontradas em suas imediações. Em /Tát Dëh/, o ritual do Dabucuri, que em língua hup é denominado/pä'-/, "fazer dabucuri", é celebrado entre os clãs /Sokw'ầt Nok'ồd Tếh D'äh/, "Filhos do Bico do Tucano" e seus afins os /Dög M'èh Tếh D'äh/, os "Filhos da Cobra-Uirapixuna". Mais à frente, em nosso acampamento (em 2015), José e Américo contaram aos rapazes a história dos antepassados que, antes de tocarem as flautas Jurupari e realizarem os Dabucuri, viajavam para as cavernas dos morros para ingerir as águas-puras das nascentes, vomitar exaustivamente até que o corpo estivesse limpo para que eles, sonhando, encontrassem ancestrais e ouvissem deles benzimentos e cantos para proteger suas famílias durante os rituais.

É justamente por andarem dentro da canoa da cobra-uirapixuna que os caminhantes se protegem das mordidas das jararacas. Esta cobra, conhecida como muçurana (Pseudoboa cloelia), é não peçonhenta e devoradora de jararacas. ${ }^{9}$ Logo, ela é uma serpente que "abre os caminhos" devorando as jararacas, uma das principais ameaças aos viajantes. Ao mesmo tempo, as muçuranas não representam perigo aos humanos, podendo ser facilmente capturadas e mesmo consumidas. A viagem na cobra-canoa faz com que, em vez de serem vistos como presas para quem o caarpi embriagante é oferecido, os viajantes estejam ocultos sob a pele fria desse poderoso predador.

Assim, a mobilização do habitus e de afecções dessa predadora-itinerário-veículo para a composição de um corpo-proteção faz os andarilhos posicionarem-se ao longo do caminho a partir do ponto de vista da muçurana, este poderoso sujeito florestal. A passagem e a indicação indexical da árvore-casa da muçurana e da paxiúba de jurupari salientam a importância da atenção para a cobra-uirapixuna e para índices que remetam aos Dabucuri. A muçurana é epônimo do clã de viajantes que são também "filhos de cobra-uirapixuna", habitante das imediações da árvore uirapixuna e devoradora de jararacas. A educação da atenção para o ponto de vista-muçurana revela-se fundamental para que os jovens "façam o caminho" a partir da percepção indexical da deixis cosmológica que situa o afeto-muçurana.

Nas viagens, dentre as várias frutas encontradas durante o trajeto, as que mais comíamos eram as deliciosas /pãhã́y/, "sorvas". Em 2012, o jovem Lucas experimentou seu terçado contra uma árvore /pãhấy/, uma sorva (seringueira). Com a lâmina feriu o tronco que começou a sangrar sua "seiva branca", /tàk/, a mesma com a qual é feita a coca que o xamã oferece às jararacas no encantamento para amordaçá-las. Na viagem de 2015, Américo comentou que, quando uma pessoa sangra, coloca-se a seiva dessa árvore para fazer curativo. Em sonhos, a seiva de sorva e o caldo de açaí sinalizam uma briga com sangue que acontecerá. 
No encantamento, o benzedor oferece a cuia com a coca seiva de sorva e de /mòt/ para diversos tipos de jararaca: ${ }^{10}$ o /b'áw/, /dëh-hàt/, /dëh-púp/. Nas andanças, encontramos jararacas de diversos tipos em muitos trechos, mas os viajantes sempre conseguiam vê-las e matá-las. Em 2012, Ari parou diante de um arbusto e disse ser um /tîh ŷ́y yồh/, planta medicinal utilizada quando se é mordido por jararaca. Na mesma viagem, antes de entrarmos na /pàç moy/, "casa de pedra", de /Hõpòy Paç/, "Serra de Surubim", Valter matou uma jararaca /b'àw/, dizendo ser um /b'atìb\%, "pessoa-sombra" ou espírito, vestindo uma /tz̃̂túy yùd/, "roupa de jararaca". As pessoas-sombra são espíritos potencialmente agressivos que vivem na mata. Em 2015, esses encontros se deram nas imediações do /Bisíw Hoy/, "poço de pesca de Bisiw", e de /D'ók Paç/, "Serra do Acarapuru". Sabendo que próximo a essa terra de /Bisíw/ (tipo de espírito) e próximo aos morros e "casas de pedra" de ancestrais situam-se inúmeras "casas" de /b'atìb\%, "pessoas-sombra", e cientes de que a proteção do "benzimento dos caminhos" afasta as jararacas do percurso, os rapazes explicitam sua capacidade de, como os xamãs, perceber os homens-sombra para além de suas aparências de cobra. Controlam a equivocação entre os pontos de vista e agem a partir de sua consciência da deixis cosmológica que situa espíritos-sombra como jararacas no caminho (Viveiros de Castro 1998).

Em 2012, num dado momento, Ponciano gritou para os jovens: /Yò' d'äh, to'oh hám/!, "Cabas, corram!". Nós, que andávamos compassadamente, corremos para fora da trilha, pelo meio da mata para despistar nossas perseguidoras. Em 2015, quando passamos pelo/Hó Dëh/, "igarapé fígado", José contou aos rapazes que estávamos perto do /Bisíw Hoy/, "poço do Bisiw", um de seus lugares de pescaria. Do corpo queimado de /Bisíw/, após o demiurgo ter devorado crianças hup, suas parceiras de troca no Dabucuri, surgiram as flautas jurupari com as quais se realiza a iniciação masculina. Indicando a toponímia, José chamava a atenção dos jovens para a presença e vida desse perigoso ancestral, tido também como um /b'atíb'/, "homem-sombra". A passagem pela /yò' moy/, "casa das cabas", e pela área de pesca do ser canibal exige a fuga e a evitação.

No benzimento, as cabas são mencionadas pelo xamã em meio à nomeação de seres (abelhas, vespas, cabas jararacas, cobras-de-duas-cabeças, Gente-árvore e Gente-Sombra), de seus /hềh/, "pertences", e de suas /d'apb'ùy tëg/, "armas", plenas de potências primordiais: cuias de caarpi, caniços e bastões de dança. Nomeando os seres e os objetos em diálogos situados no mundo desses outros interlocutores, o xamã age sobre as armas, separa suas potências dos sujeitos, externando-as como objetos rituais dados por demiurgos num tempo mítico. Pela /bi ’id ìd/, "lin- 
guagem dos benzimentos", o xamã nomeia os objetos a partir do ponto de vista de seus interlocutores, valendo-se de uma tradução por equivocação controlada (Viveiros de Castro 2004:9) para, habilidosamente, convidar os agressores potenciais ao repouso. Pacifica-os.

Em seus diálogos de pacificação, o xamã faz com que larguem suas armas sobre o jirau de suas casas. O risco de um encontro como o que tivemos com jararacas-b 'atìb' (cobras-espíritos), cabas e gente-árvore é o da mordida venenosa, vista como oferecimento convidativo da cuia de caarpi, do ponto de vista de jararacas e cabas; o risco de ser perfurado pelos galhos pontudos, vistos como bastões de dança por pessoas-sombra e gentes-árvore, o risco de ser atingido por árvores e troncos que caem, vistos como caniços para espancamento ritual por gentes-árvore e pessoas-sombra. Ao nomear os "ferrões", /tihh-tùk/, das cabas como "caniços", /hõp käk súk/ e o "veneno", /nàm/, como "cuias de caarpi", /kapi b'ò'/, o narrador realiza uma tradução como uma equivocação controlada para referir-se aos ferrões e ao veneno, a partir de um instrumento de espancamento (Dabucuri), e de um recipiente ritual para o oferecimento de caarpi (Kapiwaia) (Viveiros de Castro 2004). Atingidos pelo caniço (varas), ou bastões de dança (lanças), os viajantes figuram como presas de seus agressores.

No caminho, Ari parou para analisar um tronco de árvore e viu um / moytùd/, "urumutum" (Nothocrax urumutum) correr de sua /mòy/, "toca/ casa" quando ele se aproximava. Comentou que ele era /tẽhin pã̀/, "sem esposa", vivia solitário naquela casa. Ao perceber a aproximação de Ari, o urumutum voou para o meio dos arbustos. Nas duas viagens, durante as pescarias noturnas, sentados em diferentes pontos dos igarapés, os pescadores sopravam as mãos em concha fazendo leves movimentos de abrir e fechar para se comunicarem a partir da /moytùd ̀̀d/, "fala de urumutum". O som dos pássaros de hábitos noturnos vez por outra entrecortava a conversa dos pescadores. Sua morada e sua vida solteira ou matrimonial evidenciavam sua posição de sujeito humano, cujo ponto de vista situado em seu corpo-casa permitia que os viajantes mobilizassem a instrumentalidade de suas capacidades vocais. Por vezes, ao ouvirem ou encontrarem um urumutum na mata, era comum que os caminhantes dissessem: /tihh-sắw/, "pajé". Os urumutums são também /tihh-sấw nìh hoh tềg/, "canoa de pajé", veículos que habilitam seu deslocamento aéreo. Como as muçuranas, o afecto-urumutum pode situar o modo de ação estruturante do arranjo corpo-itinerário-veículo.

Em ambas as viagens, ao perceberem a fuga de um tatu, seus rastros ou sua toca em troncos caídos, os rapazes abaixavam-se para analisar seus rastros, cutucavam suas casas com varas e vedavam as saídas com o 
barro incandescente das casas de cupim, uma tocha que asfixia o bicho com a fumaça. As /yềw moy/, "casas de tatu", chamam sempre a atenção dos viajantes que se referem a esse animal como um coveiro noturno responsável pelo sepultamento de ancestrais. Seu corpo concentra afecções importantes para ações xamânicas agressivas (sopros). Sua habilidade de fuga por buracos faz com que a ele seja atribuída a capacidade de invisibilidade. No mesmo sentido, as pacas são tidas como hábeis fugitivos extremamente competentes na ação xamânica de ocultar-se seja por meio de buracos ou círculos de fumaça. Os encontros com pacas renderam sempre boas caças com o abate sendo feito com arco-e-flecha ou o facão. Outro animal cujo habitus é referido à noite e/ou escuridão e que chama a atenção dos andarilhos é o morcego. Em 2015, percebendo um morcego escondido no oco de uma árvore morta, Mauro iluminou a cavidade com a lanterna e jogou terra no roedor que saiu voando perturbado. A passagem pelas "casas" escuras desses seres sempre suscita comentários sobre a socialidade humana desses animais e sobre suas capacidades e habitus relevantes para a metamorfose transespecífica dos xamãs.

Caçadores noturno e possivelmente encontrado nos morros (lugares sagrados) para os quais nos dirigíamos, as onças revelavam sempre sua presença imanente por meio de suas pegadas, urina e carcaças de suas vítimas. Em 2012, quando arriscávamos passos no alto da "serra da anta", Valdemar deparou-se com uma onça-preta deitada nas pedras. Estancou seus movimentos e fez sinais para que não falássemos e recuássemos devagar. Fugimos. Na festa de caxiri de nossa chegada, dias depois, o pajé Armando riu dizendo que corremos medrosamente quando o vimos trajando sua / ya'ám yùd/, sua roupa de onça.

No "encantamento dos caminhos", o benzedor dirige-se à floresta, à casa da /ya'am tếh/, "onça pequena/jaguatirica", e segue pela floresta como uma jaguatirica para proteger os viajantes. Como os andarilhos cujo deslocamento se dá por meio de sucessivas passagens por casas de animais, o xamã vai à casa-folha de tabaco e ao caminho da lagarta, faz com que sentem portando seus instrumentos de poder (cigarro e banco) e mobiliza para si sua capacidade transformacional. A metamorfose da lagarta em borboleta a leva a voar de uma planta de tabaco (aldeia) à outra, como um xamã, fazendo crescer seus "filhos", /tếh d'äh/, e os pés de tabaco. Mencionando-a numa parte intermediária do benzimento, o xamã mobiliza sua capacidade corporal de transformação, seu voo, papel germinador e a ontologia ecológica de sua morada, sua casa de tabaco, alinhando-se pelo modo de ação: corpo-itinerário-veículo.

A interação transespecífica com a lagarta evidencia a continuidade entre as categorias de /sáp/ "corpo", /mòy/ "casa", /hayám/ "aldeia" e /tìw/ 
"caminho" como loci de perspectivas ontológicas atravessadas pelo xamã e pelos viajantes. Quando se valem da "linguagem dos benzimentos", os xamãs e os viajantes referem-se ao corpo hup como composto por diferentes casas. $\mathrm{O}$ sopro vital situa-se no peito, na /hãg sák mòy/, "casa do pulsar", enquanto o pensamento situa-se na /b'otók mòy/, "casa do ouvido". Há ainda a /katít mòy/, "casa da garganta/fala", e a /tồj mòy/, "casa do nariz/respiração". Essas casas estão interligadas por /titt/, "fios", também referidos como /sáp tìw/, "caminhos corporais". Interligadas por esses caminhos/fios, as casas circundam um Lago-de-Leite situado na região peitoral, onde se situa o sopro vital. O conjunto formado por casas, caminhos e lago compõe uma paisagem mítica. Trata-se de um corpo-paisagem concebido à imagem do cenário de surgimento da humanidade, o "Lago-de-Leite", /Pùd-dëh Mòh/. Como para muitos povos da região, é no Lago-de-Leite que surgem os diversos grupos humanos que, após a viagem no interior da Cobra-Canoa, povoarão o Alto Rio Negro. Corpos, casas, aldeias e caminhos dos animais surgem assim como províncias ontológicas, conjuntos de afectos e capacidades que são ativadas pelo xamã.

O xamã acessa os corpos-afecções do muçum, dos lagartos, do tico-tico, do curió, dos esquilos cinza e vermelho, e da jaguatirica sempre se deslocando para suas casas, fazendo com que entrem, sentem-se em seus bancos vitais e fumem seus cigarros primordiais. As lagartas metamorfoseiam-se em mariposas e voam de planta de tabaco em planta de tabaco polinizando e colonizando-as; o muçum vive na água, respira e pode migrar para dentro da terra - são fêmeas no início da vida e depois se tornam machos; os esquilos vivem na copa (alto), dentro e fora das árvores, podendo correr rapidamente pelo solo florestal (baixo). Chegar à aldeia (paisagem ontológica), adentrar a casa, penetrar o corpo e seguir pelo caminho para postar-se em pé diante de seus interlocutores fumantes sentados são sequências de ações repetidas pelo xamã. Permitem a ele valer-se das capacidades, dos instrumentos e das energias desses seres imanentes a seus corpos, habitus e mundos.

Os encontros com espíritos, sejam eles potenciais, por atravessarmos suas áreas próximas às suas moradas, ou ocorridos oniricamente, geravam também modos diferentes de relação entre os andarilhos. Ao despertar, era comum que jovens e senhores conversassem sobre seus deslocamentos em sonho e fossem executados benzimentos para a proteção, caso tivesse havido interação perigosa com pessoas-sombra ou onças. Nas duas viagens, os caminhantes beberam a água das nascentes dos morros para limparem o corpo e aprenderem os encantamentos contados por antepassados nos encontros oníricos. No benzimento, como o líquido do maracujá, a água doce da caverna tem princípios que curam e purificam o corpo, sendo considerada uma /yồh-dëh/, uma "água-pura". Em 2012, ao levar os rapazes para 
conhecerem as grutas de/D'òk Paç/e/B 'ồ'-Paç/, Ponciano contou que tinham sido Casas de Semente de Tabaco, ancestral que, como os antigos, ingeria grandes quantidades de "água da serra", /pàç dëh/, vomitava e dormia para ouvir seus antepassados ensinarem encantamentos em sonho. No chão havia restos de cerâmica espalhados. Designadas pelos Hupd'äh como/b'ok b'ah/, "lascas", eram os fragmentos da "cuia de beber água", /ầg b'o'/, e da "cuia de comer", /wèd $\mathrm{b}^{\prime} \mathrm{o}^{\prime}$ /, do ancestral. Como dito acima, em 2015, Américo e José também contaram sobre o ancestral Semente de Tabaco, mostraram os /hòn höd/, "buracos de eméticos", onde os antigos vomitavam a água, e apontaram todos os índices do caminho que remetessem aos Dabucuri.

As múltiplas metamorfoses realizadas pelo xamã no benzimento $\left(C_{;}\right.$; Movs. 6, 7, 8) envolvem o deslocar-se entre "casas", /mòy/, /sáp/, "corpos", /hayám/, "aldeias", e /tìw/, "caminhos" para mobilizar para si afecções, capacidades e instrumentalidades de seus corpos, habitus e pontos de vista configurados a partir do princípio estruturante do corpo-itinerário-veículo. A caminhada e a educação da atenção dos viajantes envolvem os encontros com animais e espíritos que se dão igualmente através do deslocamento e da passagem por suas "casas", da observação de seu habitus e de suas perspectivas.

\section{Formas constantes de interação e paralelismo}

O paralelo entre o discurso xamânico e a viagem aos morros permite entrever a continuidade entre corpos, casas e aldeias que podem ser tomados como conjuntos de afecções e lugares de perspectivas. Os muitos "corpos" e "casas" parecem ser loci de diferenciação das perspectivas (Cesarino 2008:46), instrumentos expressivos através dos quais o xamã itinerante vai metamorfoseando-se e fabricando suas "roupas" e as proteções dos viajantes a partir de uma sequência de metamorfoses interespecíficas, inter-residenciais e interecológicas. Essas repetições constantes no discurso xamânico imanente e no itinerário da viagem apontam para um macroparalelismo. Esse macroparalelismo ritual (Urban 2000:83) pode ser observado pelas grandes unidades discursivas repetidas e similares umas às outras, pela sequência de passagens por "casas" e pela ocorrência de encontros interespecíficos tomadas como formas constantes de interação (Houseman \& Severi 2009:163). A educação da atenção para a deixis cosmológica parece delinear-se, assim, a partir da percepção para o entorno orientada por sequências de encontros e diálogos interespecíficos.

Semelhante à nomeação sequencial no discurso xamânico, o gesto de apontar com a mão e a sucessão de "atos de mostrar" vão explicitando para os 
jovens as "casas" e as áreas onde determinadas presas podem ser encontradas (Ingold 2000:233). Durante as passagens por aldeamentos antigos, toda uma paisagem de memórias e afetos vai sendo criada para que os rapazes observem aquelas paragens e reconheçam os caminhos dos ancestrais que levam às serras e a outras moradas. Modos de situar-se nas casas atravessadas pelo caminho, os encontros e os comentários delineiam o fluxo de um paralelismo que permite aos rapazes a aquisição da habilidade de situar-se e controlar equivocações para agir entre pontos de vista, exercício fundamental para a caça, para a metamorfose interespecífica, para o aprendizado dos encantamentos e para a viagem às paisagens míticas (Wright 2013).

O paralelismo mostra-se também como um princípio de organização estrutural da exegese do "encantamento dos caminhos", estando presente em diferentes níveis da estrutura linguística e discursiva (Jakobson 1966; Fox 1971; Urban 2000). No encantamento, o paralelismo é empregado em movimentos, seções e em linhas, diferindo quanto aos níveis e ao longo da exegese para marcar transições de ações, nomear entidades, listar características ou objetos (armas) dessas entidades, descrever ações do xamã (ex.: "entro e fico em pé" repetido ao longo do texto).

Repetidas vezes, no decorrer da exegese, são utilizados verbos de movimento, como/ham-/, "ir", e/yë-/, "entrar", para descrever os deslocamentos do xamã da morada de um grupo de seres para outra (ver Ramos \& Epps 2017). No início de cada movimento (/hàm/), o enunciador faz uma síntese da ação anterior, geralmente com o emprego do verbo que representa a ação seguido pelo sufixo sequencial -yö' (verbo-yö', "tendo feito") e frequentemente do enclítico/b'ay/ "repetição", indicando que cada fase na ação tem a ver com a fase prévia. O deslocamento do xamã para uma nova casa cósmica expressa-se discursivamente pelo uso de verbos de movimento (/ham- 'ir', /widham- 'chegar', /d'öb-/ 'descer a declive para rio/igarapé' etc.); do advérbio/tế/ - 'até'; e do sufixo direcional/-an/ e locativo posposicional/sö́/. Essas repetições em sentenças sintaticamente semelhantes criam o paralelismo como um modo de descrição da mobilidade xamânica. Quando se referem às ações do xamã, essas expressões são utilizadas no início ou no final do movimento, descrevendo o deslocamento e a chegada a uma nova morada.

Evidencia-se assim a agência xamânica como um modo de ação marcado pela mobilidade característica das viagens cósmicas realizadas pelo benzedor através de sua palavra e de seu deslocamento cosmológico (pessoa-sopro). A alternância entre as breves narrações dos deslocamentos pelo uso dos verbos de movimento (dinâmica) e as longas descrições das "falas para" os diversos interlocutores habitantes das várias casas cósmicas visitadas (estática) apontam uma prática discursiva que busca a cura e a proteção a partir da inserção de si (xamã) em diversos campos relacionais 
(casas-cósmicas) para, agindo entre perspectivas, gerar mudanças atitudinais (voltar para casa, largar as armas, comer a coca grudenta) e emocionais (fazer entristecerem-se) em seus interlocutores através do manejo correto da potência das palavras.

Os diálogos interespecíficos com animais e espíritos envolvem a ação verbal de /no-/, "falar (para)", por meio da qual o enunciador, posicionado /k'ët-/, "estar em pé", na "casa" do interlocutor, nomeia, valendo-se da comunicação por equivocação controlada, cada uma das armas (ponto de vista hup) - pertences (objetos rituais primordiais) desses seres. As nomeações seriais de seres e objetos primordiais (armas/pertences) e o uso recorrente de expressões de movimento geram um paralelismo que contribui para a descrição da mobilidade xamânica, situando contextualmente a deixis cosmológica das perspectivas imanentes aos corpos-casas-mundos. Desse modo, as rápidas alusões aos deslocamentos entre casas parecem apontar para uma forma paralelística semelhante ao assíndeto - figura de linguagem na qual se omitem os termos de ligação, as conjunções e os verbos - enquanto as longas nomeações seriais de seres, objetos e casas permitem a composição cosmográfica de casas-corpos-mundos que, como sinédoques de campos ontológicos, sintetizam o mundo vivido e o habitus dos interlocutores xamânicos.

\section{Considerações finais}

Diante da ênfase dos estudos sobre formas e práticas discursivas do xamanismo ameríndio nos elementos que remetem a deslocamentos, itinerários, movimentos, e da constatação da "viagem" como metáfora fundamental do xamanismo no Alto Rio Negro, buscou-se ressaltar como, no discurso xamânico hup, o exame atento do paralelismo dos encantamentos revela dimensões marcantes das formas constantes de interação entre os caminhantes, salientando um macroparalelismo ritual que faz convergirem padrões discursivos e padrões de mobilidade. De certo modo, muito da complexidade do xamanismo hup revela-se por essa convergência entre agência xamânica e agência perambulatória. O aprendizado da palavra xamânica não se faz apenas pela "memorização de fórmulas verbais", como levam a crer alguns trabalhos sobre as práticas xamânicas na região (Buchillet 1983; Reichel-Dolmatoff 1978). Tal aprendizado realiza-se também por meio da participação em percursos conduzidos por mentores que visam ao engajamento prático dos rapazes com as matérias afetivas, sensórias, mnemônicas e interacionais a entrelaçar campos perspectivos de prática e vida. 
O paralelo entre discurso xamânico e mobilidade territorial permitiu observar as caminhadas para os lugares sagrados como modos de inserir os mais jovens num processo de educação da atenção para a deixis cosmológica atravessada por itinerários que levam a antigos aldeamentos e a morros. Atentos aos seus próprios movimentos e às palavras dos mais velhos, os rapazes aprendem simultaneamente a "fazer os caminhos florestais" e a "fazer os caminhos xamânicos". A cada passo integram uma vasta região plena de rotas e trilhas antigas. Abertas por demiurgos que habitaram as casas de pedra, esses percursos eram refeitos periodicamente pelos antepassados para aprendizados xamânicos e a realização dos dabucuri. O sopro do encantamento no início da viagem prepara os corpos e as percepções dos andarilhos para os encontros e os diálogos interespecíficos na passagem pelas casas de animais e espíritos. Os atos de mostrar, os comentários e as narrativas dos senhores guiam os rapazes para sentidos imanentes às paisagens e para os modos de se posicionarem entre pontos de vista, entre metamorfoses, entre intenções predatórias e entre domínios.

Pelos caminhos florestais e pelos deslocamentos xamânicos, diversas multiplicidades coexistem, penetram-se e mudam de lugar (Deleuze \& Guattari 1995:60). Os modos de ação estruturados pelo princípio corpos-casas-caminhos podem ser tomados como alinhamentos ontológicos para a interação, a comunicação e a metamorfose. Assim, a cobra-canoa muçurana é também um caminho para os andarilhos, e uma gigantesca predadora para as jararacas. O corpo hup é a paisagem mítica composta por casas e caminhos em torno do Lago-de-Leite. O pajé é a onça-preta que deixa seus rastros pelo caminho e observa os viajantes a partir de sua casa-morro. A lagarta arrasta-se pelo caminho da folha de tabaco, voa de uma casa-planta à outra como mariposa e pisa firme no solo da aldeia em sua chegada. É por meio dessa indexicalidade cosmológica que o xamã se metamorfoseia a partir do corpo-casa-mundo desses seres, aponta verbalmente para seus instrumentos de poder, suscita posicionamentos a partir dos quais seus pontos de vista, afectos e capacidades (corpo-itinerário-veículo) podem ser acessadas para sua própria e alheia metamorfose pela roupa, ocultamento pelo cercar e deslocamento pelo veículo.

Os caminhos antigos, as Casas-de-Pedra e as Moradas Antigas parecem indicar, como já afirmava Reid (1979), uma existência social e o convívio de longa duração nessas regiões, o que é evidenciado pela semelhança entre os itinerários dos ancestrais e aqueles dos pais e avós dos viajantes hup. A identificação de tantos assentamentos, lugares sagrados, artefatos, a reabertura de caminhos antigos, com as descrições das práticas rituais nas Casas-de-Pedra, revelam as cabeceiras como pontos de referência para os 
padrões de mobilidade hup. Se os modelos sociológicos regionais assinalam um sistema multiétnico de geografias xamânicas integrados pelas rotas arawak e tukano que interligam paisagens míticas de modo hidrocêntrico (Hill 2011; Cayón \& Chacon 2014; Vidal 1999), a cartografia cosmológica hup delineada pelas rotas e pelos caminhos florestais para os morros parece conectar uma vasta região pela axis interfluvial. Percorrendo tais caminhos e bebendo a água das nascentes, os rapazes vão seguindo os passos de seus predecessores e aprendendo à medida que se posicionam na matriz dos movimentos que constituem a Terra Hup para defendê-la por meio de seus passos e palavras de poder.

Recebido em 20 de abril de 2017

Aprovado em 23 de fevereiro de 2018

Danilo Ramos é pós-doutorando da Universidade de São Paulo, Brasil . Email: <danilo.ramos@usp.br>

Patience Epps é professora do Departamento de Linguística, Universidade do Texas, EUA. Email: <pattieepps@austin.utexas.edu> 


\section{Notas}

* Ambos os autores do artigo vêm desenvolvendo pesquisa de campo e atividades de assessoria a projetos de Saúde, Educação e Gestão Territorial junto à comunidade hup de Taracuá-Igarapé, /Tạt Dëh/, onde habitam aproximadamente 202 indivíduos, e que está situada em território hup às margens do igarapé de mesmo nome, afluente do rio Tiquié. Há, ao todo, 26 casas onde moram 38 grupos domésticos.

1 A maior capacidade para abordar essa relação entre discurso xamânico e mobilidade sociocósmica vem sendo semeada desde os trabalhos de Bateson (2000). Enfatizando as continuidades entre natureza e cultura e entre a mente e o mundo, Bateson (2000) lançou bases férteis para pensar a ecologia na inter-relação entre o sujeito e o mundo, tomando a mente não como produtora de representações culturais, mas sim como forma de mediação ativa com o entorno. Num caminho próximo, os trabalhos de Basso (1984, 1988, 1996a, 1996b) sobre os Apache ocidentais mostraram a importância da relação entre discurso, espaço e mobilidade para o modo como percepções, sensações e experiências vinculam-se ao passado mítico e à história. No mesmo sentido, Feld (1996) mostrou como os lugares são nomeados e evocados poeticamente pelos Kaluli, permitindo construções sensíveis e expressivas da paisagem onde o olhar, ver e ouvir são conectados pela experiência do lugar. Propondo-se a pensar a relação entre caminhadas pela mata e as dimensões pessoais, míticas e históricas inscritas na paisagem por meio do conceito de "escrita topográfica", Santos-Granero (1998) analisa o modo como os Yanesha escrevem a história de modos sutis na paisagem.

2 De forma próxima, explorando as relações dos Runa com seres não humanos, Kohn (2013) enfoca a comunicação e o aprendizado interespécies, compondo uma etnografia "para além do humano".

3 A mobilidade socioespacial dos Hupd'äh e dos povos Naduhup pode ser vista como um dos principais temas trabalhados pela literatura etnológica. A imagem dos povos Maku como nômades mostra-se fundamental para os trabalhos de Koch-Grünberg (1909, 1906), Tastevin (1923) e Nimuendajú (1982). A partir dos estudos de Silverwood-Cope (1990) e Reid $(1978,1979)$, passa-se a enfocar os padrões de mobilidade e a alternância entre a aldeia, a floresta e o trabalho nas aldeias tukano da beira-rio. Atento às dinâmicas das relações de parentesco e à organização social, Pozzobon (2011) analisa a fluidez e o improviso em relação a regras sociais em paralelo com os conflitos entre ágnatos que culminam em processos de cisão e mobilidade social. Mais recentemente, os trabalhos de Ramos (2013) e Lolli (2010) abordaram a relação entre mobilidade, xamanismo e vida ritual. Deve ser destacado o trabalho de Marques (2015) sobre as transformações nos padrões de mobilidade ocasionadas pelas constantes incursões à cidade pelos Hupd'äh.

4 Essa mesma sequência de deslocamentos em exegeses de encantamentos Desana foi descrita por Buchillet (1983) igualmente como movimentos.

5 /d'òk/, "acarapuru": certo tipo de jeju pequeno, peixe teleósteo caraciforme da família dos eritrinídeos, Erythrinus sp. (cf. Ramirez 2006).

6 Ver os Planos de Gestão Territorial e Ambiental deterras indígenas, ferramentas de implementação da Política Nacional de Gestão Ambiental e Territorial de Terras Indígenas (PNGATI): Visam à "valorização do patrimônio material e imaterial 
indígena, à recuperação, à conservação e ao uso sustentável dos recursos naturais, assegurando a melhoria da qualidade de vida e as condições plenas de reprodução física e cultural das atuais e futuras gerações indígenas" (Funai 2013:6).

\section{Fundação Nacional do Índio.}

8 /Tiw täm/, "caminho cerrado", vem a ser o modo como os Hupd'äh denominam esses caminhos de menor circulação atual e que precisam ser abertos. Seu fechamento é explicado, em parte, pela mudança no modo de vida das grandes aldeias, onde os jovens rapazes se voltam para a pesca em rios grandes e igarapés próximos e se dedicam à caça em áreas não tão distantes. Já as moças e jovens mulheres voltam-se cada vez mais para o trabalho nas roças, igualmente próximas às aldeias. Desde 2006, muitas famílias têm também permanecido meses na cidade de São Gabriel da Cachoeira por conta de salários, benefícios sociais e documentos básicos. Assim, esses "caminhos cerrados" são percorridos atualmente apenas por famílias de benzedores de grande poder e pelas famílias dos pajés para colheita de plantas medicinais, veneno de caça, realização de ações rituais e caça. Mais recentemente, tais caminhos voltaram a ser percorridos por jovens e senhores para o etnomapeamento dos Planos de Gestão Territorial e Ambiental (PGTA). Para alguns senhores, o fechamento dos caminhos representa também algo semelhante à ação xamânica de cercar, protegendo os morros sagrados e os antigos aldeamentos da entrada de não indígenas e de pessoas de outras etnias.

9 De acordo com Von Ihering (1940), essa cobra é tida como uma "limpa mato". A palavra muçurana origina-se do tupi e seu significado evoca a semelhança dessa serpente com o muçum, peixe próximo à enguia. Em tupi, além do termo muçurana, essa cobra também é chamada /boirú/, "a cobra que come outras cobras" (Von Ihering 1940:539).

10 A dificuldade em identificar diferencialmente e de acordo com as classificações zoológicas esses tipos de cobras peçonhentas se deve, dentre outros motivos, ao fato de os Hupd'äh denominarem "jararaca", em português, a uma grande variedade de serpentes que, em língua hup, são diferenciadas pelos nomes e formas de classificação. 


\section{Referências bibliográficas}

ANDRELLO, Geraldo; MARTINI, André; ALVES, Renata \& OLIVEIRA, Ana Gita de. 2012. "Mapeando lugares sagrados: patrimônio imaterial, cartografia e narrativas em Iauaretê". In: Geraldo Andrello (org.), Rotas de criação e transformação: narrativas de origem dos povos indígenas do Rio Negro. São Paulo: ISA; São Gabriel da Cachoeira: FOIRN. pp. 18-41.

ARHEM, Kaj. 1998. "Powers of place: territory, landscape and belonging in northwest Amazonia". In: Nadia Lowell (org.), Local belonging. London: Routledge. pp. 78-102.

ATHIAS, Renato. 1995. Hupdah-Maku/ Tukano: les rélations inègales entre deux societés du Uaupés Amazonien (Brésil). Tese de Doutorado em Antropologia, Université de Paris X, Nanterre, Paris. . 2006. "Os Hupd'äh". In: Henri Ramirez (org.), A língua dos Hupd'äh do Alto Rio Negro. São Paulo: Saúde Sem Limites. pp. $09-20$.

AUSTIN, J. L. 1962. How to do things with words. Cambridge (MA): Harvard University Press.

BASSO, Keith. 1996a. Wisdom sits in places: landscape and language among the Western Apache. Albuquerque: University of New Mexico Press. . 1996b. "Wisdom sits in places: notes on a Western Apache landscape". In: S. Feld \& K. Basso (orgs.), Senses of place. Santa Fe, New Mexico: School of American Research Press. pp. $53-90$.

. 1988. "Speaking with names: language and landscape among the Western Apache". Cultural Anthropology, 3(2):99-130.

. 1984. "Stalking with histories: names, places, and moral narratives among the Western Apache". In: E.
Bruner (org.), Text, play, and history. Long Grove, Illinois: Waveland Press. pp. 19-55.

BATESON, Gregory. 2000. Steps to an ecology of mind. Chicago: University of Chicago Press.

BEIER, C.; MICHAEL, L. \& SHERZER, J. 2002. "Discourse forms and processes in indigenous lowland South America: an areal-typological perspective". Annual Review of Anthropology, 31:121-145.

BIDOU, P. \& PERRIN, M. (orgs.). 1988. Lenguaje y palavras chamánicas. Quito, Ecuador: Ed. Abya-Yala.

BUCHILLET, Dominique. 1983. Maladie et mémoire des origins chez les Desana du Uaupés. Ph.D. Dissertation, Université de Paris X. . 1992. "Nobody is there to hear: Desana therapeutic incantations". In: E. Matteson, Jean Langdon \& Gerhard Baer (orgs.), Portals of power: shamanism in South America. Albuquerque: University of New Mexico Press. pp. $211-230$.

CAYÓN, Luis. 2008. "Ide ma, el camino de agua. Espacio, chamanismo y persona entre los Makuna". Antípoda Revista de Antropología y Arqueología, 1(7):141-173.

CAYÓN, Luis; CHACON, Thiago. 2014. "Conocimiento, historia y lugares sagrados. La formación del sistema regional del alto río Negro desde una visón interdisciplinar". Anuário Antropológico/2013, Brasília, UnB, 39(2):201-233.

CARNEIRO DA CUNHA, Manuela. 1998. "Pontos de vista sobre a floresta amazônica". Mana. Estudos de Antropologia Social, 4(1):07-22.

CESARINO, Pedro. 2013. Oniska: poética do xamanismo na Amazônia. São Paulo: Perspectiva. 
. 2013. "Cartografias do cosmos: conhecimento, iconografia e artes verbais entre os Marubo". Mana. Estudos de Antropologia Social, 19(3):437-471.

CESARINO, Pedro. 2008. "Babel da floresta, cidade dos brancos?". Novos Estudos, 18 (1): 133 - 148.

CHAUMEIL, Jean-Pierre. 1983. Voir, savoir, pouvoir. Paris: Ed. EHESS.

CHERNELA, Janet \& LEED, Eric. 1996. "Shamanic journeys and anthropological travels". Anthropological Quarterly, 69(3):129-133.

DE CERTEAU, Michel. 2011. A invenção do cotidiano. Vol. 1. Petrópolis: Vozes.

DELEUZE, G. \& GUATTARI, F. 1995. Mil platôs. Vol. 1. São Paulo: Ed. 34. EPPS, Patience. 2008. A grammar of Hup. Berlin: Mouton de Gruyter. .; BOLAÑOS, Katherine. 2017. "Reconsidering the 'Makú' family of northwest Amazonia". International Journal of American Linguistics, 83(3):467-507.

.; RAMOS, Danilo. 2017. "Enactive aesthetics: the ethnopoetics of incantation". Paper presented at the Workshop: Rethinking Native American Discourse: Rhetoric and Poetics 30 years later, Universidade do Texas, Austin. Mimeo.

FOX, James. 1971. "Semantic parallelism in Rotinese ritual language". Royal Netherlands Institute of Southeast, Asian and Caribbean Studies, 46(3):215-255.

FAVRET-SAADA, Jeanne. 2009. Désorceler. Paris: Éditions de l'Olivier.

FELD, Stephen. 1996. "Waterfall song". In: S. Feld; K. Basso (orgs.), Senses of place. Santa Fe, New Mexico: School of American Research Press, pp. pp. $91-135$.

FUNDAÇÃO NACIONAL DO ÍNDIO. COORDENAÇÃO GERAL DE GESTÃO AMBIENTAL (org.). 2013. Pla- no de Gestão Territorial e Ambiental de Terras Indígenas: Orientações para Elaboração. Brasília: Funai.

GALLOIS, Dominique. 1996. "Xamanismo Waiãpi". In: Esther Langdon (org.), Xamanismo no Brasil. Florianópolis: Ed. UFSC. pp. 39 - 74.

GELL, Alfred. 1998. Art and agency. Oxford: Caledon Press.

GOW, Peter. 2001. An Amazonian myth and its history. New York: Oxford University Press.

HILL, Jonathan. 1989. "Ritual reproduction of environmental history among the Arawakan Wakuénai of Venezuela". Human Ecology, 17(1):1-25. . 1993. Keepers of the sacred chants. Tucson: University of Arizona Press. . 2011. "Sacred landscapes as environmental histories in lowland South America". In: A. Hornborg \& J. Hill (orgs.), Ethnicity in ancient Amazonia. Boulder: University Press of Colorado. pp. 259 - 278.

HOUSEMAN, Michael; SEVERI, Carlo. 2009. Naven ou le donner à voir. Paris: CNRS-Éditions.

HUGH-JONES, Christine. 1979. From the milk iver. Cambridge: Cambridge University Press.

HUGH-JONES, Stephen. 1979. The palm and the Pleiades. Cambridge: Cambridge University Press. . 1995. "Сoca, beer, cigars and yage". In: J. Goodman; P. Lovejoy \& A. Sherratt (orgs.), Consuming habits. London and New York: Routledge. pp. $46-64$.

. 2012. "Escrever na pedra, escrever no papel". In: Geraldo Andrello (org.), Rotas de criação e transformação: narrativas de origem dos povos indígenas do Rio Negro. São Paulo: ISA; São Gabriel da Cachoeira: FOIRN. pp. 138-167.

HYMES, Dell. 1981. In vain I tried to tell you. Essays in native American eth- 
nopoetics. Philadelphia: University of Pennsylvania Press.

INGOLD, Tim. 2000. The perception of the environment. London: Routledge. JACKSON, Jean. 1983. The fish people. Cambridge: Cambridge University Press.

JAKOBSON, R. 1966. "Grammatical parallelism and its Russian facet". Language, 42(1):398-429.

KOCH-GRÜNBERG, T. 2005 [1909]. Dois anos entre os indígenas. Manaus: EDUA/ FSDB. . 2010 [1906]. "Die Maku". In: G. Becerra (org.), Viviendo en el bosque. Medellín: Ed. Universidad Nacional de Colombia. pp. 29 - 36.

KOHN, Eduardo. 2013. How forests think. Berkeley: University of California Press.

LANGDON, E. J. 2013. "A viagem à casa das onças?: Narrativas sobre experiências extraordinárias". Revista de Antropologia, 56(1):183-212.

LOLLI, Pedro. 2010. As redes de trocas rituais dos Yuhupdeh no igarapé Castanha, através dos benzimentos (mihdïd) e das flautas jurupari (Ti'). Tese de doutorado, Universidade de São Paulo.

MARQUES, Bruno. 2015. Os Hupd'äh e seus mundos possíveis. Tese de Doutorado, Museu Nacional-UFRJ.

NEVES, Eduardo. 2001. "Indigenous historical trajectories in the Upper Rio Negro Basin". In: Colin MCewan; Cristiana Barreto \& Eduardo Neves (orgs.), Unknown Amazon: culture and nature in ancient Brazil. London: The British Museum Press. pp. 266-286.

. 2011. "Archaeological cultures and past identities in the Pre-colonial Central Amazon". In: Alf Hornborg \& Jonathan Hill (orgs.), Ethnicity in ancient Amazonia: reconstructing past identities from archeology, linguistics, and ethnohistory. Boulder: University Press of Colorado. pp. 31-56.

NIMUENDAJÚ, C. 1982. Textos indigenistas. São Paulo: Ed. Loyola.

PERRIN, Michel. 2001. Les praticiens du rêve: un exemple de chamanisme. Paris: PUF.

POZZOBON, Jorge. 2011. Sociedade e improviso. Rio de Janeiro: Museu do Índio/ Funai.

RAMIREZ, Henri. 2006. A língua dos Hupd'äh do Alto Rio Negro. São Paulo: Saúde Sem Limites.

RAMOS, Alcida (org). 1981. Hierarquia e simbiose: relações intertribais no Brasil. Brasília: Hucitec.

RAMOS, Danilo. 2013. Círculos de coca e fumaça: encontros noturnos e caminhos vividos pelos Hupd'äh (Maku). Tese de Doutorado, Universidade de São Paulo.

RAMOS, Danilo \& EPPS, Patience. 2017. "Enactive aesthetics: the ethnopoetics of incantation". Workshop: Rethinking Native American Discourse - Rethoric and Poetics 30 years latter. Austin.

REICHEL-DOLMATOFF, Gerardo. 1978. El chamán y el jaguar. Bogotá: Ed. Siglo Veintiuno. . 1986. Desana. Bogotá: Procultura.

REID, Howard. 1978. "Dreams and their interpretation among the Hupd'äh Maku Indians of Brazil". Cambridge Anthropology, 4(3):2-29. . 1979. Some aspects of movement, growth and change among the $\mathrm{Hu}$ pdu Maku Indians of Brazil. Ph.D. Dissertation, University of Cambridge.

SANTOS-GRANERO, Fernando. 1998. "Writing history into the landscape: space, myth, and ritual in contemporary Amazonia". American Ethnologist, 25(2):128-148.

SEEGER, Anthony. 1986. "Oratory is spoken, myth is told, and song is 
sung, but they are all music to my ears". In: Joel Sherzer \& Greg Urban (orgs.), Native South American discourse. Berlin: Mouton de Gruyter. pp. 59-82.

SEVERI, Carlo. 2002. "Memory, reflexivity and belief". Social Anthropology, 10(1):23-40.

SILVERWOOD-COPE, P. 1990. Os Makú: povo caçador do noroeste da Amazônia. Brasília: Ed. Universidade de Brasília.

TASTEVIN, P.C. 1923. "Les Makú du Japurá". Journal de la Société del Américanistes. Paris, 15 (1): 99-108.

TEDLOCK, Dennis. 1983. The spoken word and the work of interpretation. Philadelphia: University of Pennsylvania Press.

TOWNSLEY, Graham. 1993. "Song paths: The ways and means of Yaminahua shamanic knowledge". L'Homme, 33(126):449-468.

URBAN, Greg. 2000. A discourse-centered approach to culture: Native South American myths and rituals. Austin: University of Texas Press.

VIDAL, S. 1999. "Amerindian groups of northwest Amazonia: their regional system of political-religious hierarchies." Anthropos, 94(4/6):515-528. . 2000. "Kuwé Duwákalumi: The Arawak sacred routes of migration, trade, and resistance". Ethnohistory, $47(3 / 4): 635-667$.

VIDAL，S. \& ZUCCHI，A. 2000. "Los caminos del Kuwai". In: L. Herrera \&
M. Schrimpff (orgs.), Caminos precolombinos: las vias, los ingenieros y los viajeros. Bogotá: Imprenta Nacional de Colombia. pp. 87 - 112.

VIVEIROS DE CASTRO, Eduardo. 1996. "Os pronomes cosmológicos e o perspecti- vismo ameríndio". Mana. Estudos de Antropologia Social, 2(2):115-144.

VIVEIROS DE CASTRO, Eduardo. 1998. "Cosmological deixis and Amerindian perspectivism". The Journal of the Royal Anthropological Institute, 4(3):469-488.

. 2004. "Perspectival anthropology and the method of controlled equivocation". Tipití, 2(1):3-22. . 2002. A inconstância da alma selvagem. São Paulo: Cosac \& Naify. . 2008. "Xamanismo transversal". In: Rubens Queiroz \& Renade F. Nobre (orgs.), Lévi-Strauss: leituras brasileiras. Belo Horizonte: Ed. UFMG. pp. 87 - 136.

VON IHERING, R. 1940. Dicionário dos animais do Brasil. São Paulo: Secretaria da Agricultura, Indústria e Comércio do Estado de São Paulo.

WHITEHEAD, Neil; WRIGHT, Robin (orgs.). 2004. In darkness and secrecy: the anthropology of assault sorcery and witchcraft in Amazonia. Durham: Duke University Press.

WRIGHT, Robin. 2013. Mysteries of the jaguar shamans of the northwest Amazon. Lincoln: University of Nebraska Press. 


\section{CAMINHOS DE SOPRO: DISCURSO XAMÂNICO E PERCURSOS FLORESTAIS DOS HUPD'ÄH}

\section{Resumo}

Vagarosamente, as pegadas dos viajantes Hupd'äh deixam a aldeia e seguem pelos caminhos de mata. Tateiam o solo úmido da floresta amazônica pisando e repisando percursos ancestrais. Devidamente protegidos pela ação xamânica dos anciões, os jovens caminhantes seguem seus mentores, observam plantas, paisagens, rastros e ouvem encantamentos xamânicos. Partindo da análise comparativa entre, de um lado, viagens para lugares sagrados (morros e cavernas) e, de outro, a viagem do xamã no "benzimento dos caminhos" para proteger os viajantes, busca-se evidenciar as relações entre a palavra xamânica, os caminhos vividos e os modos de mobilidade hup. Descrevendo em paralelo os aspectos de mobilidade das exegeses de encantamentos e os elementos xamânicos revelados pelas paisagens florestais, o artigo pretende mostrar a importância dos caminhos e dos lugares sagrados Hupd'äh para o chamado sistema multiétnico de geografias xamânicas do Alto Rio Negro. Em que medida, através da mobilidade dos xamãs pelas palavras e da mobilidade dos viajantes por seus passos, os Hupd'äh, povo do Alto Rio Negro-AM, descrevem seus percursos de observação e ação ao longo do mundo? Palavras-chave: Xamanismo ; Mobilidade; Discurso; Povo Hupd'äh, Alto Rio Negro.

\section{PATHS OF INCANTATION: SHAMANIC DISCOURSE AND FOREST TRAVEL AMONG THE HUPD'ÄH}

\begin{abstract}
Protected by a shaman's incantation, the young Hupd'äh travelers pick up the forest trails, embarking on a trek to visit sacred sites in their ancestral territory. Under the mentorship of their elders, these young people engage with the ecological and topographic details of their lands in historical and cosmological context, underscored by discussions of history, mythology, dreams, and shamanic incantations that are interspersed throughout their journey. In this article, we consider the parallels between the two types of travel that are evident in these events - treks through the forest to visit sacred ancestral locations (mountains and caves), and the metaphysical travels of ritual specialists, as detailed in the exegetic texts of the incantations performed to protect the travelers. The features of movement, dislocation between sacred places, and engagement with the flora, fauna, and landscape that are shared by these two travel experiences highlight the close articulation between ritual and more mundane experience for the Hupd'äh, as well as their mutual role in shaping young people's understanding of their world. Our discussion locates the Hupd'äh and their forest orientation within the broader 'multiethnic system of shamanic geographies' (Cayón and Chacon 2014) of the Upper Rio Negro Region.
\end{abstract}

Key words: Shamanism; Mobility; Discourse; Hupd'äh people; Alto Rio Negro region. 


\section{CAMINOS DE SOPLO: DISCURSO \\ CHAMÁNICO Y RUTAS FLORESTALES \\ DE LOS HUPD'ÄH}

\section{Resumen}

Lentamente, las huellas de los viajeros Hupd'äh dejan la aldea y siguen por los caminos de la selva. Tantean el suelo húmedo de la selva amazónica pisando y repasando rutas ancestrales. Los jóvenes caminantes siguen debidamente protegidos por la acción chamánica de los ancianos, observan plantas, paisajes, rastros y oyen el encantamiento chamánico. A partir del análisis comparativo entre, por un lado, viajes a lugares sagrados (cerros y grutas) y, por otro, el viaje del chamán en el "encantamiento de los caminos" para proteger a los viajeros, se busca evidenciar las relaciones entre la palabra chamánica, los caminos vividos y los modos de movilidad hup. Describiendo en paralelo los aspectos de movilidad de las exégesis de encantamientos y los elementos chamánicos revelados por los paisajes forestales, el artículo pretende mostrar la importancia de los caminos y de los lugares sagrados Hupd'äh para el llamado sistema multiétnico de geografías chamánicas del Alto Río Negro. ¿En qué medida, a través de la movilidad de los chamanes por las palabras y la movilidad de los viajeros por sus pasos, los Hupd'äh, pueblo del Alto Río Negro-AM, describen sus itinerarios de observación y acción a lo largo del mundo?

Palabras clave: Chamanismo; Movilidad; Discurso; Pueblo Hupd'äh; Alto Río Negro. 